\title{
Atmospheric aerosols in Rome, Italy: sources, dynamics and spatial variations during two seasons
}

\author{
Caroline Struckmeier $^{1}$, Frank Drewnick ${ }^{1}$, Friederike Fachinger ${ }^{1}$, Gian Paolo Gobbi ${ }^{2}$, and Stephan Borrmann ${ }^{1,3}$ \\ ${ }^{1}$ Particle Chemistry Department, Max Planck Institute for Chemistry, Mainz, Germany \\ ${ }^{2}$ Institute of Atmospheric Sciences and Climate, ISAC-CNR, Rome, Italy \\ ${ }^{3}$ Institute for Atmospheric Physics, Johannes Gutenberg University, Mainz, Germany \\ Correspondence to: Caroline Struckmeier (c.struckmeier@mpic.de) and Frank Drewnick (frank.drewnick@mpic.de)
}

Received: 22 July 2016 - Published in Atmos. Chem. Phys. Discuss.: 5 August 2016

Revised: 14 November 2016 - Accepted: 17 November 2016 - Published: 9 December 2016

\begin{abstract}
Investigations on atmospheric aerosols and their sources were carried out in October/November 2013 and May/June 2014 consecutively in a suburban area of Rome (Tor Vergata) and in central Rome (near St Peter's Basilica). During both years a Saharan dust advection event temporarily increased $\mathrm{PM}_{10}$ concentrations at ground level by about $12-17 \mu \mathrm{g} \mathrm{m}^{-3}$. Generally, in October/November the ambient aerosol was more strongly influenced by primary emissions, whereas higher relative contributions of secondary particles (sulfate, aged organic aerosol) were found in May/June. Absolute concentrations of anthropogenic emission tracers (e.g. $\mathrm{NO}_{x}, \mathrm{CO}_{2}$, particulate polycyclic aromatic hydrocarbons, traffic-related organic aerosol) were generally higher at the urban location. Positive matrix factorization was applied to the $\mathrm{PM}_{1}$ organic aerosol (OA) fraction of aerosol mass spectrometer (HR-ToF-AMS) data to identify different sources of primary OA (POA): traffic, cooking, biomass burning and (local) cigarette smoking. While biomass burning OA was only found at the suburban site, where it accounted for the major fraction of POA (18-24\% of total $\mathrm{OA})$, traffic and cooking were more dominant sources at the urban site. A particle type associated with cigarette smoke emissions, which is associated with a potential characteristic marker peak $\left(m / z 84, \mathrm{C}_{5} \mathrm{H}_{10} \mathrm{~N}^{+}\right.$, a nicotine fragment) in the mass spectrum, was only found in central Rome, where it was emitted in close vicinity to the measurement location. Regarding secondary OA, in October/November, only a very aged, regionally advected oxygenated OA was found, which contributed $42-53 \%$ to the total OA. In May/June total oxygenated OA accounted for $56-76 \%$ of the OA. Here a fraction (18-26\% of total OA) of a fresher, less oxygenated OA
\end{abstract}

of more local origin was also observed. New particle formation events were identified from measured particle number concentrations and size distributions in May/June 2014 at both sites. While they were observed every day at the urban location, at the suburban location they were only found under favourable meteorological conditions, but were independent of advection of the Rome emission plume. Particles from sources in the metropolitan area of Rome and particles advected from outside Rome contributed $42-70$ and 30-58 \% to the total measured $\mathrm{PM}_{1}$, respectively. Apart from the general aerosol characteristics, in this study the properties (e.g. emission strength) and dynamics (e.g. temporal behaviour) of each identified aerosol type is investigated in detail to provide a better understanding of the observed seasonal and spatial differences.

\section{Introduction}

Atmospheric aerosol particles remain a major uncertainty, both in estimations of climate change (Boucher et al., 2013) and regarding the impact of air pollution on public health (Heal et al., 2012) and, therefore, are a major topic of current research (Fuzzi et al., 2015). Identifying the sources, properties and concentrations of atmospheric particles is essential for evaluating their effect on climate and health and constitutes a crucial step in finding measures for the improvement of air quality.

Many studies on aerosols and their sources have been carried out in urban environments (e.g. Freutel et al., 2013; Mohr et al., 2012; Zheng et al., 2005), which are character- 
ized by high population densities and a large diversity of particle sources. Typical urban aerosol sources include road traffic, cooking and heating activities. Emissions from biomass burning can also be significant, both with a regional origin (e.g. agricultural fires and wildfires; Reche et al., 2012) and from residential wood combustion, which recently has become more prominent in Europe, even in urban environments (Fuller et al., 2013).

Many of these anthropogenic sources emit large amounts of organic material in the fine particle fraction (e.g. Hildemann et al., 1991). In recent studies of particle source identification (e.g. Allan et al., 2010; Mohr et al., 2012; Reche et al., 2012), positive matrix factorization (PMF) was applied to separate the organic aerosol (OA) fraction into different factors associated with various OA sources, thereby providing indications about the fraction of primary and secondary organic aerosol (POA and SOA; Zhang et al., 2011). Oxygenated organic aerosol (OOA), mainly associated with SOA, is typically found to be the most abundant fraction of OA (Lanz et al., 2010), with concentrations depending on season and location (Zhang et al., 2011). Several studies, mainly from observations during summertime (Lanz et al., 2010), show discrimination of OOA into a fresher and a more aged type of OOA based on different states of oxygenation and/or volatility (Jimenez et al., 2009).

While AMS measurements yield useful information on the age of OA, they cannot provide evidence for new particle formation of fresh secondary aerosol. Indications of such events, however, can be found in physical aerosol properties like particle number concentration or size distribution (e.g. Alam et al., 2003). New particle formation events in urban environments have been investigated previously in several studies (e.g. Alam et al., 2003; Brines et al., 2015; Minguillon et al., 2015; Shi et al., 2001; Zhang et al., 2004) and seem to be responsible for elevated particle number concentrations in southern Europe especially in the early afternoon (Reche et al., 2011).

On the other hand, while the health impact of coarse particles $\left(\mathrm{PM}_{10}-\mathrm{PM}_{2.5}\right)$ is not yet fully understood (Heal et al., 2012), the association between Saharan dust advections and mortality/hospitalization is quite well demonstrated (Stafoggia et al., 2016). Deserts are large sources for mineral dust, which can strongly contribute to atmospheric $\mathrm{PM}_{10}$ levels, especially in southern Europe. Measurements performed in the period 2001-2004 during Saharan dust advections over Rome showed a mean Saharan dust contribution of 12$16 \mu \mathrm{g} \mathrm{m}^{-3}$ to daily $\mathrm{PM}_{10}$ concentrations, leading to an average annual increase of about $2 \mu \mathrm{g} \mathrm{m}^{-3}$ (Gobbi et al., 2013). In the central Mediterranean region, maximum dust concentrations are typically observed from spring to autumn (Barnaba and Gobbi, 2004).

In this study, we investigate the occurrence and properties of ambient aerosol from different types of sources in Rome, which apart from local emissions can be influenced by advected aerosol from continental Europe and the Sahara.
During two different seasons (October/November 2013 and May/June 2014) and at two different locations (city centre and suburb), stationary measurements of chemical and physical properties of aerosols, several trace gases and meteorological variables were performed. Non-refractory components of submicron particles were measured with an Aerodyne high-resolution time-of-flight aerosol mass spectrometer (HR-ToF-AMS). To support the identification, strength and temporal behaviour of particle sources, the OA measured with the HR-ToF-AMS was further separated into different factors using PMF.

Based on these measurements, in this work the urban atmosphere of Rome is investigated in terms of particle source identification with a special focus on seasonal and spatial differences, influencing the presence and/or the characteristics of aerosol types in the city area.

\section{Experimental section}

\subsection{Measurement locations and periods}

Measurement results presented in this study were obtained during four intensive field campaigns in the greater Rome area, Italy (Table 1). The city of Rome covers an area of $1300 \mathrm{~km}^{2}$ and has a population of about 2.9 million residents (about 4.3 million residents within the whole metropolitan area of $5350 \mathrm{~km}^{2}$ ). Three airports are located in the Rome province, including the largest one in Italy (Fiumicino). Heavy industries are not found in Rome; the economy is mainly based on services, education, construction, tourism, etc. Parks and gardens cover some $34 \%$ of the city area. Rome is characterized by high traffic volume and density: about $50 \%$ of the population commutes every day, mainly by private cars. The cars per capita ratio in the city is 550 per 1000 inhabitants.

Measurements referred to as DIAPASON were performed in October/November 2013 and May/June 2014 at the Institute of Atmospheric Sciences and Climate (CNR-ISAC) in Tor Vergata, Rome. The institute is located in the southeastern outskirts of the city $\left(41^{\circ} 50^{\prime} 30.2^{\prime \prime} \mathrm{N}, 12^{\circ} 38^{\prime} 51.2^{\prime \prime} \mathrm{E}\right.$, $103 \mathrm{~m}$ a.s.1., $14 \mathrm{~km}$ from central Rome) and considered to be an urban background site. The measurement platform MoLa (see Sect. 2.2) was positioned on a free field with no buildings within a radius of $200 \mathrm{~m}$. A frequently used street is located at approximately $100 \mathrm{~m}$ distance in northerly direction. The closest highway (A1) is situated south-westerly at a distance of about $700 \mathrm{~m}$. Single-house suburbs are scattered over this territory, starting some $1 \mathrm{~km}$ from the site. Frascati, a town on the Alban Hills, is located at about $4 \mathrm{~km}$ distance in south-easterly direction. During both periods measurements at Tor Vergata were supported by the EC-LIFE+ project DIAPASON (Desert-dust Impact on Air quality through model-Predictions and Advanced Sensors ObservatioNs), which aims to improve existing tools to as- 
Table 1. Summary of measurement campaigns and measurement periods. Date format is dd.mm.yyyy.

\begin{tabular}{llll}
\hline Campaign name & Measurement location & Classification & Measurement period \\
\hline DIAPASON2013 & Tor Vergata & Urban background & 23.10.-07.11.2013 \\
POPE2013 & Central Rome & Urban & 07.11.-14.11.2013 \\
DIAPASON2014 & Tor Vergata & Urban background & 20.05.-04.06.2014 \\
POPE2014 & Central Rome & Urban & $04.06 .-17.06 .2014$ \\
\hline
\end{tabular}

Table 2. Summary of the instruments deployed in MoLa during all measurement periods, together with measured variables. $D_{\mathrm{p}}$ : particle diameter (defined according to individual instrumental measurement method: optical, aerodynamic or mobility diameter).

\begin{tabular}{|c|c|}
\hline Instrument & Measured variable \\
\hline \multicolumn{2}{|c|}{ Chemical composition of $\mathrm{PM}_{1}$} \\
\hline Aerosol mass spectrometer (HR-ToF-AMS) & $\begin{array}{l}\text { Organics, sulfate, nitrate, ammonium, chloride } \\
\text { (non-refractory) mass concentrations }\left(D_{\mathrm{p}}=\sim 70-800 \mathrm{~nm}\right)\end{array}$ \\
\hline Multi-Angle Absorption Photometer (MAAP) & Black carbon $(\mathrm{BC})$ mass concentration \\
\hline PAS2000 & Particulate $\mathrm{PAH}^{\mathrm{a}}$ mass concentration \\
\hline \multicolumn{2}{|c|}{ Physical aerosol properties } \\
\hline Condensation particle counter (CPC) & Total number concentration $\left(D_{\mathrm{p}}>2.5 \mathrm{~nm}\right)$ \\
\hline Fast mobility particle sizer (FMPS) & Size distribution $\left(D_{\mathrm{p}}=5.6-560 \mathrm{~nm}\right)$ \\
\hline Optical particle counter $(\mathrm{OPC})^{\mathrm{b}}$ & Size distribution $\left(D_{\mathrm{p}}=0.25-32 \mu \mathrm{m}\right)$ \\
\hline Aerodynamic particle sizer (APS) & Size distribution $\left(D_{\mathrm{p}}=0.5-20 \mu \mathrm{m}\right)$ \\
\hline Environmental Dust Monitor (EDM) & Mass concentration of $\mathrm{PM}_{1}, \mathrm{PM}_{2.5}, \mathrm{PM}_{10}$ \\
\hline \multicolumn{2}{|c|}{ Trace gas mixing ratios } \\
\hline Airpointer & $\mathrm{NO}_{2}, \mathrm{NO}_{x}, \mathrm{NO}, \mathrm{SO}_{2}, \mathrm{CO}, \mathrm{O}_{3}$ \\
\hline LI-840 & $\mathrm{H}_{2} \mathrm{O}, \mathrm{CO}_{2}$ \\
\hline \multicolumn{2}{|r|}{ Meteorology } \\
\hline Meteorological station ${ }^{\mathrm{c}}$ & $\begin{array}{l}\text { Wind direction, wind speed, } \\
\text { temperature, pressure, solar radiation, } \\
\text { precipitation, relative humidity }\end{array}$ \\
\hline
\end{tabular}

sess the contribution of Saharan dust to local $\mathrm{PM}_{10}$ levels (http://www.diapason-life.eu/). For this reason measurements were scheduled in periods in which a dust advection event could be expected and was forecasted by a number of dust forecasts such as the DREAM8b (Basart et al., 2012), the SKIRON (Kallos et al., 1997) and the Tel Aviv University (Alpert et al., 2002) models.

The POPE (Particle Observations around St. PEter's) measurement campaigns were conducted during November 2013 and June 2014 in central Rome. Measurements were performed inside a courtyard belonging to the administration of the hospital Santo Spirito $\left(41^{\circ} 54^{\prime} 04.3^{\prime \prime} \mathrm{N}, 12^{\circ} 27^{\prime} 41.5^{\prime \prime} \mathrm{E}\right.$, $18 \mathrm{~m}$ a.s.1.), which is positioned approximately $600 \mathrm{~m}$ from $\mathrm{St}$ Peter's Basilica. This urban measurement site is surrounded by highly frequented streets, separated from the courtyard by the four-storey building of the hospital. The surrounding area is a touristic hotspot with frequent religious gatherings (e.g. festivals, masses) and many restaurants and shops. Especially on Wednesdays, during the papal audience, and on Sundays, if the masses are held at St Peter's or during papal speeches (Angelus), the area attracts numerous visitors.

The distance between the two measurement sites is around $17 \mathrm{~km}$. In both years measurements at Tor Vergata and central Rome were performed consecutively.

\subsection{Instrumentation}

All measurements were performed with a mobile aerosol research laboratory (MoLa; Drewnick et al., 2012). MoLa is based on a regular Ford Transit delivery vehicle equipped with instruments for online measurements of chemical and physical properties of aerosols, important trace gases and meteorological variables (Table 2). A further description, as well as details of the aerosol inlet system, can be found in Drewnick et al. (2012). All results presented in this study 
were obtained in stationary measurements, with the aerosol inlet and a meteorological station at $7 \mathrm{~m}$ above ground level.

An HR-ToF-AMS (Aerodyne Research, Inc.; DeCarlo et al., 2006) was used to measure particulate mass concentrations of submicron non-refractory organics (Org), sulfate $\left(\mathrm{SO}_{4}\right)$, nitrate $\left(\mathrm{NO}_{3}\right)$, ammonium $\left(\mathrm{NH}_{4}\right)$ and chloride $(\mathrm{Chl})$. The HR-ToF-AMS allows the distinction between different ions at the same nominal mass-to-charge-ratio $(\mathrm{m} / \mathrm{z})$. The instrument was run in $V$-mode i.e. the ions followed a $V$ shaped trajectory through the mass spectrometer, allowing high sensitivity at slightly lower mass resolution, compared to the higher-resolution mode ( $W$-mode).

In the framework of the EC-LIFE+ project DIAPASON additional measurements were performed at the Tor Vergata measurement site, which aimed at assessing the contribution of Saharan dust to PM levels. These measurements included hourly $\mathrm{PM}_{10}$, a 3-wavelength nephelometer, $1 \mathrm{~h}$ filter sampling for offline PIXE analysis (Lucarelli et al., 2014) and a polarization lidar-ceilometer for the assessment of presence, phase and altitude of aerosol layers (Gobbi et al., 2004). Boundary layer heights were determined from polarization lidar-ceilometer measurements based on the method described by Angelini and Gobbi (2014).

Since the POPE measurements were performed inside a courtyard surrounded by four-storey tall buildings, wind speed, wind direction and solar radiation data are affected and not used for these periods. The time resolution for all measurements is $60 \mathrm{~s}$ or better.

\section{Data preparation and analysis}

\subsection{General data analysis}

All measured variables were corrected for sampling delays and set on a common $1 \mathrm{~s}$ time base. Particle losses during the transport through the inlet system were negligible (Drewnick et al., 2012). The data time series were carefully inspected and quality checked. Data affected by instrument calibrations and malfunctions were removed. Measurement periods influenced by local emissions (e.g. moving vehicles in the immediate vicinity of MoLa) were identified based on prominent short peaks in the time series of $\mathrm{CO}_{2}$ and particle number concentration (PNC), which significantly exceeded the typical variability and were removed from the data set. After data decontamination, $5 \mathrm{~min}$ averages were calculated for all variables, which were used for all following analyses if not otherwise indicated.

Data collected during the DIAPASON2013/POPE2013 and DIAPASON2014/POPE2014 field campaigns are presented in local winter $(\mathrm{UTC}+1)$ and local summer $(\mathrm{UTC}+2)$ times, respectively. For convenience, DIAPASON2013 data are presented only in wintertime, even though the change from summer- to wintertime was at the fifth day of measurements (27 October 2013). This means data measured prior to the time change are shifted $1 \mathrm{~h}$ backwards with respect to local (summer) time. Diurnal patterns, in particular, dominated by anthropogenic activity patterns (e.g. traffic during rush hour times) could be affected by ignoring the time change. In order to evaluate this possible influence, diurnal cycles measured before and after the time change were compared, but no significant shift of diurnal patterns was observed between the two time periods. Since diurnal cycles are not only modulated by the source emission strengths, but also by boundary layer dynamics, we assume the missing evidence of the time shift in the data is caused by a combination of influence from boundary layer dynamics and the temporal uncertainty of diurnal cycles calculated over only a few days. Additionally, anthropogenic activities could have partially not been instantly adapted to the time change, which would lead to a blurring of the effect of the time change on diurnal cycles.

Polar plots of species concentration as a function of local wind direction and wind speed were generated by averaging species concentrations ( $60 \mathrm{~s}$ data) into bins of $5^{\circ}$ wind direction and $0.5 \mathrm{~m} \mathrm{~s}^{-1}$ wind speed. The resulting data were smoothed by applying a natural neighbour interpolation (Sibson, 1981). As presented by Yu et al. (2004), such polar plots can provide directional information on sources in the vicinity of a monitoring site. Sources close to the measurement site are typically indicated by concentration decreases with increasing wind speed, while pollutants which are emitted from remote sources or at higher altitudes need higher wind speeds to be transported to the monitoring site (Yu et al., 2004). Similarly, Carslaw et al. (2006) reported the capability of such bivariate polar plots to distinguish between nobuoyancy sources like traffic (decreased pollutant concentration with increasing wind speed) and buoyant plumes emitted from sources like chimney stacks (increased concentrations with increasing wind speed), in which case the plume needs to be brought down to ground level from a higher altitude.

\subsection{HR-ToF-AMS data analysis}

AMS data evaluation (more details on AMS data quality assurance can be found in the Supplement, Sect. S1) was carried out within Igor Pro 6.37 (Wavemetrics) with the standard AMS data analysis software SQUIRREL $1.55 \mathrm{H}$ and PIKA $1.14 \mathrm{H}$. Elemental ratios calculated from organic ion fragments (Aiken et al., 2007) based on the improved calibration method (Canagaratna et al., 2015) were determined using APES light 1.06 (all available at http://cires1.colorado.edu/ jimenez-group/ToFAMSResources/ToFSoftware/). For all data sets a collection efficiency of 0.5 was applied, which is typical for the given ambient measurement conditions (Canagaratna et al., 2007). The ionization efficiency (IE) of the ion source and the relative ionization efficiency (RIE) for ammonium and sulfate (e.g. Canagaratna et al., 2007) were determined before the DIAPASON and after the POPE campaigns in both years. An additional IE calibration in 2013 after the field measurements showed no general trend in IE values. 
Table 3. Summary of selected variables measured during DIAPASON (Tor Vergata) and POPE (central Rome) in 2013 and 2014 . Values represent total campaign averages, calculated from 5 min averages and their standard deviations. NA: not available.

\begin{tabular}{|c|c|c|c|c|}
\hline & $\begin{array}{r}\text { DIAPASON2013 } \\
\text { (October/November 2013) }\end{array}$ & $\begin{array}{l}\text { POPE2013 } \\
\text { (Nov 2013) }\end{array}$ & $\begin{array}{r}\text { DIAPASON2014 } \\
\text { (May/June 2014) }\end{array}$ & $\begin{array}{r}\text { POPE2014 } \\
\text { (June 2014) }\end{array}$ \\
\hline Temperature $\left({ }^{\circ} \mathrm{C}\right)$ & $17.6 \pm 2.9$ & $16.1 \pm 2.8$ & $19.0 \pm 3.5$ & $24.9 \pm 4.5$ \\
\hline $\operatorname{Rain}^{\mathrm{a}}(\mathrm{mm})$ & $46.3(5)$ & $25.9(6)$ & $6.3(5)$ & $69.9(4)$ \\
\hline Pressure (hPa) & $1004 \pm 7$ & $1009 \pm 6$ & $1002 \pm 2$ & $1012 \pm 4$ \\
\hline Solar radiation ${ }^{\mathrm{b}}\left(\mathrm{W} \mathrm{m}^{-2}\right)$ & $103 \pm 26$ & NA & $282 \pm 55$ & NA \\
\hline Rel. humidity (\%) & $78 \pm 11$ & $73 \pm 6$ & $61 \pm 15$ & $52 \pm 16$ \\
\hline Wind speed $\left(\mathrm{m} \mathrm{s}^{-1}\right)$ & $1.9 \pm 1.3$ & NA & $2.5 \pm 1.6$ & NA \\
\hline Daily BLH ${ }^{\mathrm{c}}$ max. (m) & $850 \pm 220$ & $900 \pm 150$ & $1500 \pm 450$ & $1560 \pm 250$ \\
\hline $\operatorname{TKE}^{\mathrm{d}}\left(\mathrm{J} \mathrm{kg}^{-1}\right)$ & $0.48 \pm 0.45$ & $1.8 \pm 2.3$ & $0.84 \pm 0.79$ & $0.68 \pm 0.52$ \\
\hline $\mathrm{PM}_{10}^{\mathrm{e}}\left(\mu \mathrm{g} \mathrm{m}^{-3}\right)$ & $22 \pm 12$ & $13 \pm 7$ & $15 \pm 8$ & $17 \pm 8$ \\
\hline $\mathrm{PM}_{10-2.5}^{\mathrm{e}, \mathrm{f}}\left(\mu \mathrm{g} \mathrm{m}^{-3}\right)$ & $4.5 \pm 3.1$ & $4.7 \pm 3.2$ & $9.3 \pm 6.5$ & $7.1 \pm 5.7$ \\
\hline $\mathrm{PM}_{1}^{\mathrm{e}}\left(\mu \mathrm{g} \mathrm{m}^{-3}\right)$ & $15 \pm 10$ & $6.0 \pm 3.6$ & $5.8 \pm 3.5$ & $7.5 \pm 3.8$ \\
\hline $\mathrm{PM}_{1}(\mathrm{AMS}+\mathrm{BC})^{\mathrm{g}, \mathrm{i}}\left(\mu \mathrm{g} \mathrm{m}^{-3}\right)$ & $12 \pm 8$ & $5.6 \pm 4$ & $8.7 \pm 5$ & $12.5 \pm 6$ \\
\hline $\operatorname{PNC}^{\mathrm{h}}\left(10^{3} \mathrm{~cm}^{-3}\right)$ & $23 \pm 15$ & $27 \pm 11$ & $18 \pm 10$ & $13 \pm 5$ \\
\hline $\mathrm{NO}_{x}(\mathrm{ppb})$ & $29 \pm 27$ & $36 \pm 27$ & $9 \pm 9$ & $13 \pm 8$ \\
\hline $\mathrm{CO}_{2}(\mathrm{ppm})$ & $410 \pm 20$ & $420 \pm 20$ & $410 \pm 20$ & $420 \pm 20$ \\
\hline $\mathrm{O}_{3}(\mathrm{ppb})$ & $14 \pm 14$ & $8.9 \pm 10$ & $34 \pm 19$ & $35 \pm 22$ \\
\hline $\mathrm{PAH}\left(\mathrm{ng} \mathrm{m}^{-3}\right)$ & $45 \pm 54$ & $45 \pm 39$ & $10 \pm 14$ & $12 \pm 11$ \\
\hline $\operatorname{Org}^{\mathrm{i}}\left(\mu \mathrm{g} \mathrm{m}^{-3}\right)$ & $5.3 \pm 4.5$ & $2.5 \pm 1.8$ & $4.5 \pm 3.2$ & $6.6 \pm 3.3$ \\
\hline $\mathrm{SO}_{4}\left(\mu \mathrm{g} \mathrm{m}^{-3}\right)$ & $2.0 \pm 1.1$ & $0.48 \pm 0.44$ & $1.6 \pm 0.44$ & $2.6 \pm 1.3$ \\
\hline $\mathrm{NO}_{3}\left(\mu \mathrm{g} \mathrm{m}^{-3}\right)$ & $0.86 \pm 0.80$ & $0.23 \pm 0.17$ & $0.61 \pm 0.72$ & $0.49 \pm 0.40$ \\
\hline $\mathrm{NH}_{4}\left(\mu \mathrm{g} \mathrm{m}^{-3}\right)$ & $0.88 \pm 0.48$ & $0.20 \pm 0.18$ & $0.66 \pm 0.27$ & $0.97 \pm 0.46$ \\
\hline $\operatorname{Chl}\left(\mu \mathrm{g} \mathrm{m}^{-3}\right)$ & $0.09 \pm 0.16$ & $0.04 \pm 0.06$ & $0.06 \pm 0.13$ & $0.03 \pm 0.08$ \\
\hline $\mathrm{BC}\left(\mu \mathrm{g} \mathrm{m}^{-3}\right)$ & $2.9 \pm 2.5$ & $2.2 \pm 1.7$ & $1.3 \pm 1.0$ & $1.8 \pm 1.0$ \\
\hline
\end{tabular}

${ }^{a}$ Total accumulated amount of rain during measurements. Numbers of days with rain are given in parentheses. ${ }^{b}$ Average and standard deviation of daily means. Only days with $24 \mathrm{~h}$ measurements were used (includes $85 \%$ of data). ${ }^{c}$ Average and standard deviation of daily boundary layer height (BLH) maxima from polarization lidar-ceilometer. Measurements at the Tor Vergata site provided by the DIAPASON project (DIAPASON, 2016). ${ }^{\mathrm{d}}$ Turbulent kinetic energy (TKE) calculated from $2 \mathrm{~h}$ averages provided by Arpa Lazio Environmental Agency from measurements at 3 sites around Rome (Tor Vergata, Castel di Guido, Boncompagni). ${ }^{\mathrm{e}} \mathrm{PM}$ concentrations from EDM measurements. ${ }^{\mathrm{f}}$ Difference between $\mathrm{PM}_{10}$ and $\mathrm{PM}_{2.5}$ (coarse particles). ${ }^{\mathrm{g}} \mathrm{PM}_{1}$ concentration based on the sum of AMS species and BC. ${ }^{\mathrm{h}}$ PNC from CPC measurements. ${ }^{\mathrm{i}}$ For POPE2013 and POPE2014 corrected for contribution from local cigarette smoke emissions, compare Sect. 4.2.5.

Therefore, the observed variability of the IE values (2013: $\sim 10 \%, 2014: \sim 20 \%$ ) is assumed to stem only from the uncertainty of the calibrations and for each year averages of the determined IE and RIE values were used for data analysis. Measurements of particle free air were carried out multiple times during the campaigns and were used for correction of instrumental background effects.

In order to separate total OA into different aerosol types, PMF (Paatero and Tapper, 1994; Ulbrich et al., 2009) was applied to high-resolution mass spectra of the OA fraction with $m / z$ below 131 . This was done separately for each measurement campaign. The procedure of HR data and error matrices (matrix input sizes can be found in the Supplement) preparation is described in detail in DeCarlo et al. (2010). Isotopes constrained to a fractional signal of their parent ion were excluded from the analysis. Within the PMF Evaluation Tool v2.06 ions with signal-to-noise ratio $<0.2$ were removed from data and error matrices, and ions with signalto-noise ratio between 0.2 and 2 were down-weighted in the analysis by increasing their estimated error by a factor of 2 (Ulbrich et al., 2009). Particulate $\mathrm{CO}_{2}^{+}(\mathrm{m} / z$ 44) and its associated ions at $m / z 16,17,18$ and 28 were down-weighted by a factor of $\sqrt{5}$ (Ulbrich et al., 2009, Supplement).

In order to find the most reasonable and robust PMF solution, the number of factors ( 1 to $\leq 10$; always at least two more than the final selected solution), the rotational force parameter ( $f$ Peak: -1 to $1 ; \Delta=0.2$ ) and the starting point (seed: 0 to $50 ; \Delta=1$ ) were varied (see Ulbrich et al., 2009 for methodological details). Solutions with $f$ Peak $=0$ and seed $=0$ turned out to yield robust results for all data sets. The evaluation of potential PMF solutions was based on comparisons of the resulting factor time series with those of co-located measurements (see Sect. 4.2) and of factor mass spectra with those from the literature. Residues, i.e. the contribution of organic mass concentrations not included in any of the factors, accounted for $<1 \%$ of the organics mass concentration in all used PMF solutions and are, therefore, neg- 
DIAPASON2013

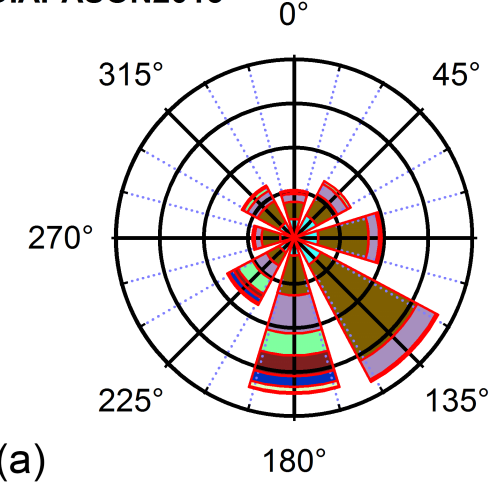

DIAPASON2014

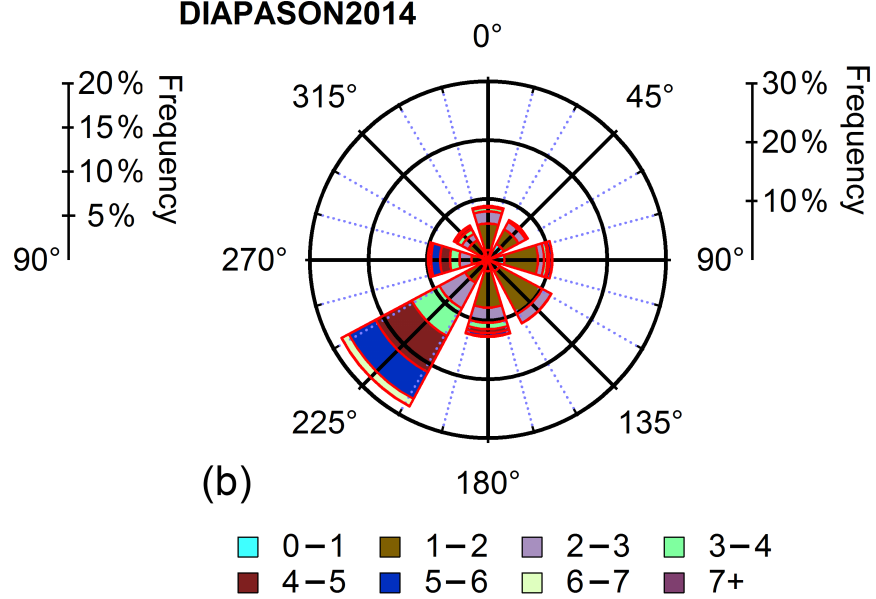

Figure 1. Relative frequency of local wind directions (in ${ }^{\circ}$ ) colour coded with wind speed measured during DIAPASON2013 (left) and DIAPASON2014 (right).

ligible. Mass spectra and time series of each identified PMF factor can be found in the Supplement.

\section{Results and discussion}

\subsection{Overview: differences between seasons and locations}

This section provides a broad overview of the mean conditions of local meteorology and air quality during each measurement campaign (Table 3, Fig. 1) and discusses their seasonal and spatial differences. Figure 2 provides an overview of the relative composition of non-refractory $\mathrm{PM}_{1}$ plus $\mathrm{BC}$ and shows the contribution of different factors related to different sources retrieved from the OA fraction using PMF. In total, seven different PMF factors were identified: OOA (oxygenated OA), SV-OOA (semi-volatile OOA), LV-OOA (low-volatile OOA), HOA (hydrocarbon-like OA), COA (cooking OA), BBOA (biomass burning OA) and CSOA (cigarette smoke OA, see Sect. 4.2.5; considered local contamination and not included in the pie charts in Fig. 2). Here, only a general overview of these different factors focusing on seasonal and spatial differences is given. A more detailed discussion of the various sources associated with these factors is provided in Sect. 4.2.

\subsubsection{Meteorology overview}

The first period of the DIAPASON2013 campaign (23-31 October 2013) was dominated by high pressure influences and low wind speeds with air masses moving from the Atlantic across northern Africa and the Mediterranean basin. Within this period dust from the Sahara was transported to the Rome area (see Sect. 4.2.1). The second half of DIAPASON2013 (1-7 November 2013) was characterized by a pressure drop and increased wind speed together with some frontal passages leading to precipitation. Both turbulent kinetic energy (TKE), which is a measure of the intensity of turbulence and can be used as an indicator for the mixing efficiency of pollutants in the air (Srivastava and Sarthi, 2002), and boundary layer heights (BLH) were at rather low levels during DIAPASON2013 (Table 3), favouring the accumulation of pollutants.

The first measurement days of POPE2013 (7-9 November 2013) were influenced by changing weather conditions, followed by a low-pressure system centred over Italy (10-14 November 2013) driving N-NW wind conditions and leading to almost daily precipitation events. High TKE levels (almost 3 times higher than those during DIAPASON2013) and slightly increased boundary layer heights ( $900 \mathrm{~m}$ compared to $850 \mathrm{~m}$; Table 3) led to conditions in which dilution of pollutants was more favoured.

During DIAPASON2014 a low-pressure system was located over the Atlantic and northern Africa. Saharan dust was advected to the measurement site during the first week of measurements (Rizza et al., 2016). Some precipitation events occurred during these advections. TKE was slightly higher after the dust advection, favouring the reduction of pollutant concentrations. Boundary layer heights reached around $1500 \mathrm{~m}$ (Table 3).

During POPE2014 a period of low pressure over the Atlantic and high pressure over Africa and Europe (4-13 June 2014) was followed by reversed conditions (14-17 June 2014) with some heavy precipitation events. Compared to DIAPASON2014 the boundary layer was slightly higher $(1560 \mathrm{~m})$ and TKE was decreased by $20 \%$.

During DIAPASON2013 local winds were predominantly arriving from south and south-easterly directions, whereas during DIAPASON2014 south-westerly wind directions dominated (Fig. 1; no data available for POPE2013/2014, see 


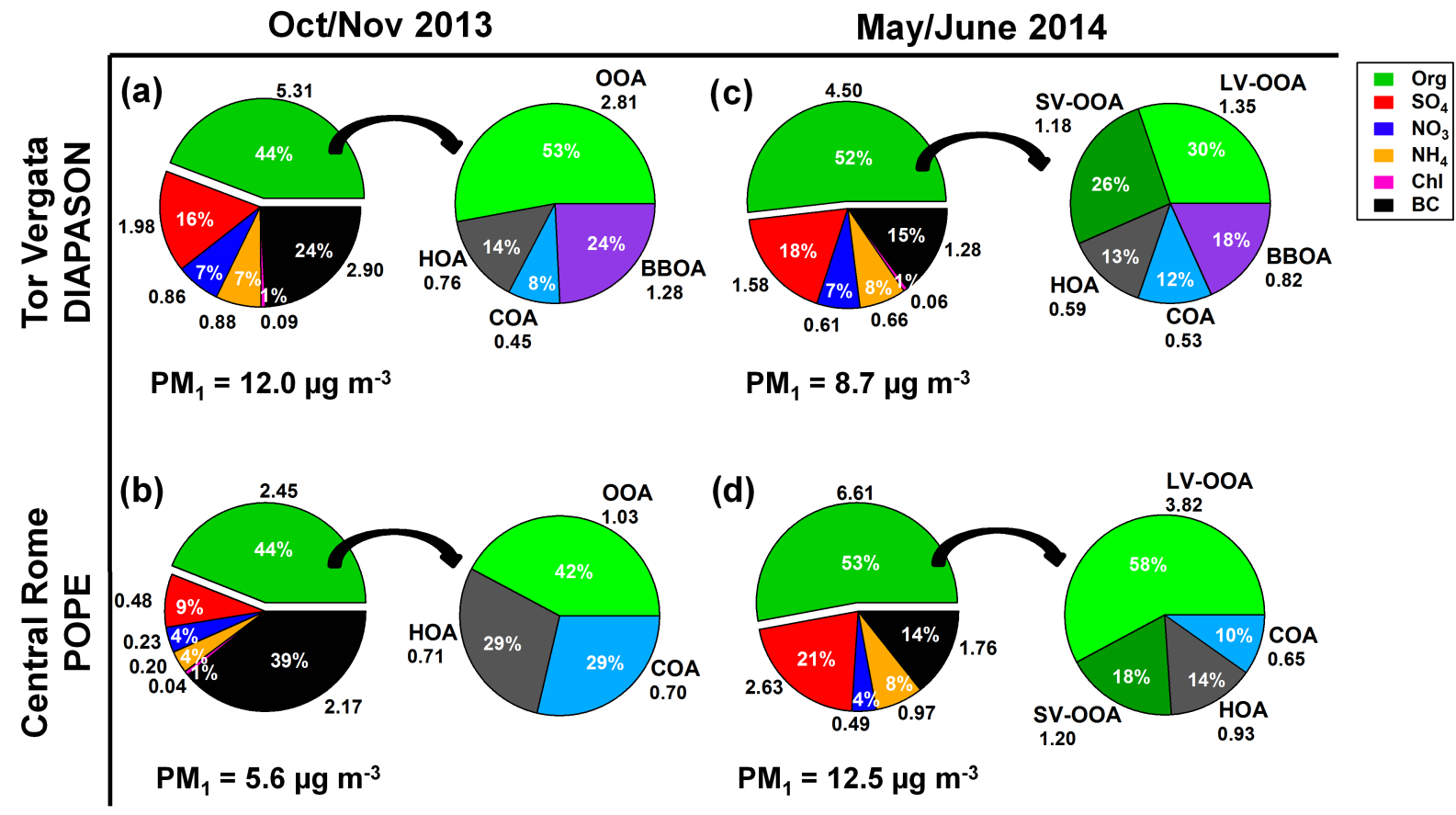

Figure 2. Mean chemical composition $\left(\mu \mathrm{g} \mathrm{m}^{-3}\right.$ ) of non-refractory $\mathrm{PM}_{1}$ together with $\mathrm{BC}$ (left chart in panels a-d) and PMF-separated organic fraction (right chart in panels $\mathbf{a}-\mathbf{d}$ ) for each measurement period. $\mathrm{PM}_{1}$ values below the pie charts represent total mass concentration of AMS-measured species plus BC. The organic fraction measured in central Rome was corrected for contributions from cigarette smoke in the local environment (Sect. 4.2.5, it was also omitted from the pie charts depicting the PMF-separated organic fraction).

Table 4. Estimated contribution of home-made and advected species to total $\mathrm{PM}_{1}$ for all measurement periods. Dust advection periods and emissions from cigarettes are excluded.

\begin{tabular}{lrr}
\hline & $\begin{array}{r}\text { Home-made } \mathrm{PM}_{1} \\
\left(\mu \mathrm{g} \mathrm{m}^{-3}\right) \\
(\text { contribution to } \\
\left.\mathrm{PM}_{1} ; \%\right)\end{array}$ & $\begin{array}{r}\text { Advected } \mathrm{PM}_{1} \\
\left(\mu \mathrm{g} \mathrm{m}^{-3}\right) \\
(\text { contribution } \\
\left.\text { to } \mathrm{PM}_{1} ; \%\right)\end{array}$ \\
\hline DIAPASON2013 & $6.5(47)$ & $7.3(53)$ \\
POPE2013 & $3.9(70)$ & $1.7(30)$ \\
DIAPASON2014 & $4.7(59)$ & $3.3(41)$ \\
POPE2014 & $5.2(42)$ & $7.3(58)$ \\
\hline
\end{tabular}

Sect. 2.2). No clear relationship between air mass origin and measured $\mathrm{PM}_{1}$ mass concentrations was found using HYSPLIT (Stein et al., 2015) and FLEXPART (Stohl et al., 2005) back trajectories for our measurement periods.

\subsubsection{Aerosols and trace gases}

During both October/November and May/June measurements, $\mathrm{CO}_{2}, \mathrm{NO}_{x}$ and particulate $\mathrm{PAH}$ concentrations (all typically traffic related) were higher in central Rome than in the suburb (Table 3). Cooking-related aerosol (COA) concentrations were found to be generally higher in the city centre (Fig. 2b, d), while traffic-related (HOA) concentra- tions were strongly increased during $2014(+58 \%)$ at the urban location and were nearly the same at both locations during the 2013 measurements (Fig. 2a, b). All this is consistent with increased primary emissions (cooking, traffic) at the urban site (Fig. 2b, d) compared to the suburban site (Fig. 2a, c). However, total concentrations of organic aerosol predominantly of primary origin (POA) were higher at the suburban location $\left(1.9-2.5 \mu \mathrm{g} \mathrm{m}^{-3}\right)$ than at the urban location $\left(1.4-1.6 \mu \mathrm{g} \mathrm{m}^{-3}\right)$. This is due to a factor indicating particles from biomass burning (BBOA), which was obtained exclusively at Tor Vergata (Fig. 2a, c). Here, biomass burning seems to be an important particle source, contributing the most abundant fraction (42-51\%) of POA. Note that, due to the fact that OOA concentrations are significantly higher in the suburban site in 2013, the relative contribution of POArelated aerosol types (i.e. HOA, COA and BBOA) is lower at the suburban location during this year. However, in order to avoid a bias in the comparison of the more locally generated POA-related aerosol types by advected aerosol mass, we compare the absolute mass concentrations for the different aerosol types at the different measurement locations/times. $\mathrm{BC}$, which is related to primary emissions from both biomass burning and traffic, showed no general trend between the two locations (Table 3). Ratios of HOA/BC (DIAPASON2013: 0.26, POPE2013: 0.33, DIAPASON2014: 0.46, POPE2014: 0.53 ) were lower during fall 2013 , indicating the more dominant contribution of biomass burning emissions to $\mathrm{BC}$ during 
this time. The fact that contributions from biomass burning to total $\mathrm{BC}$ concentrations are non-negligible was also found earlier (e.g. Crippa et al., 2013a). Generally, the HOA/BC ratios were higher at the urban location than at the suburban location in each year. This reflects the stronger influence of traffic emissions and the lower contribution of biomass burning emissions in the city centre.

The influence of increased temperatures and stronger solar radiation during measurements in May/June 2014 (Table 3) is reflected in elevated ozone mixing ratios and the fact that it was possible to extract an additional OOA factor, which was attributed to a fresher, less oxidized aerosol type (SV-OOA, Fig. 2c, d). This SV-OOA is likely the result of quick formation of secondary aerosol from precursors originating from the greater Rome area. Within a continuum of OOA with different degrees of aging/oxidation, SV-OOA (fresh, of rather local origin) and LV-OOA (aged, of more regional origin) are located in the upper and lower ranges, respectively. In contrast, in October/November, only one type of rather aged OOA was found (Fig. 2a, b) due to reduced photochemistry in this season which prevents the quick formation of oxygenated aerosol from precursors emitted in the vicinity.

A stronger influence of aged aerosol of predominantly regional origin on the $\mathrm{PM}_{1}$ fraction was observed for May/June than for October/November: the fraction of OOA (SV-OOA + LV-OOA) to OA, as well as the relative contribution of total organics and sulfate to $\mathrm{PM}_{1}$, was higher in the warmer season (Fig. 2c, d). This could be caused by different prevalent air mass origins, though the analysis of back trajectories provided no definite answers on this (see above). The relative fraction of sulfate could also be lower in October/November due to an enhanced contribution of primary particles (Table 3 ) as a consequence of lower boundary layer heights (which limits the dilution of locally produced aerosols while it does not influence the concentration of transported aerosols) and, potentially, higher emission strength of local sources during the colder season. Consistently, in October/November 2013 at both measurement locations a higher BC fraction was observed compared to May/June, and POA made up a larger fraction of the total measured organics (Fig. 2). Absolute BC concentrations were also enhanced. Additionally, higher concentrations of $\mathrm{NO}_{x}$ and PAH (increased by a factor of 3) and total particle number concentrations (PNCs) were observed in October/November (Table 3), indicating the accumulation of pollutants during the colder season due to the aforementioned reasons.

\subsubsection{Home-made vs. advected $\mathrm{PM}_{1}$}

For a rough estimate of the contribution of $\mathrm{PM}_{1}$ originating from sources in the Rome metropolitan area and from advection from outside, $\mathrm{PM}_{1}$ species were separated into "homemade" (BC, HOA, COA, BBOA, SV-OOA, $\mathrm{NO}_{3}$ ) and "advected" (OOA/LV-OOA, $\left.\mathrm{SO}_{4}\right)$ (Table 4$) . \mathrm{NH}_{4}$ was appor- tioned to home-made and advected $\mathrm{PM}_{1}$ based on the molar concentrations associated with $\mathrm{NO}_{3}$ and $\mathrm{SO}_{4}$, respectively. Not included in these estimates are dust advection periods and emissions from cigarettes (which were considered as local contaminations). While nitrate is formed quickly, thus strongly contributes to the home-made aerosol fraction, it can also be transported. The resulting fraction of homemade aerosol might, therefore, be slightly biased high, but by a few percent at most due to the small total contribution of nitrate to $\mathrm{PM}_{1}$. For the POPE2013 measurements OOA shows only poor correlations with $\mathrm{SO}_{4}$, but slightly better ones with $\mathrm{NO}_{3}$, suggesting either a local contribution of OOA or the transport of $\mathrm{NO}_{3}$. Whatever the case may be, it will contribute to the error of the estimation. During the measurements the fraction of home-made $\mathrm{PM}_{1}$ accounted for $42-70 \%$ and advected $\mathrm{PM}_{1}$ accounted for $30-58 \%$ of total (home-made and advected) $\mathrm{PM}_{1}$ (Table 4). During the 2013 measurements higher absolute concentrations of home-made $\mathrm{PM}_{1}$ were found at the suburban location than at the urban site, possibly caused by meteorological conditions favouring pollutant accumulation during the respective period (see above). However, due to the large differences in total $\mathrm{PM}_{1}$, the relative contribution of home-made $\mathrm{PM}_{1}$ was higher at the urban location. During 2014, when meteorological conditions (e.g. BLH, TKE; see Table 3) were rather comparable at both locations, similar absolute concentrations of home-made $\mathrm{PM}_{1}$ were observed at both sites. No general seasonal difference in home-made $\mathrm{PM}_{1}$ fraction was observed, although BLH was strongly increased during the May/June 2014 compared to the October/November 2013 measurement periods. Partially, this might be due to the additional presence of the home-made species SV-OOA in May/June, which could to some extent have compensated for the dilution effect due to the increased BLH. Altogether, neither a general spatial (DIAPASON vs. POPE) nor a seasonal (October/November vs. May/June) tendency regarding the contribution of home-made and advected $\mathrm{PM}_{1}$ to total $\mathrm{PM}_{1}$ was observed. These results indicate that urban air quality in Rome strongly depends on emissions within the city and transport of pollutants to the city, both of which contribute to the urban aerosol concentration.

Independently of measurement season and location, the organics fraction was always found to contribute the largest share of $\mathrm{PM}_{1}$ (44-53\% of non-refractory $\mathrm{PM}_{1}$ plus $\mathrm{BC}$, Fig. 2), though its relative composition (primary vs. secondary OA) differed. Regarding absolute $\mathrm{PM}_{1}$ concentrations (Table 3 from EDM measurements, Fig. 2 from nonrefractory components plus BC) neither a general conclusion as to whether aerosol mass concentrations are higher in the city centre or in the suburb nor whether $\mathrm{PM}_{1}$ concentrations are elevated during any of the two different seasons can be drawn. In the 2013 campaign, total PM $_{1}$ mass concentrations were more than doubled at the suburban location compared to the urban location, whereas in the 2014 measurement $\mathrm{PM}_{1}$ concentrations were increased by a factor of 


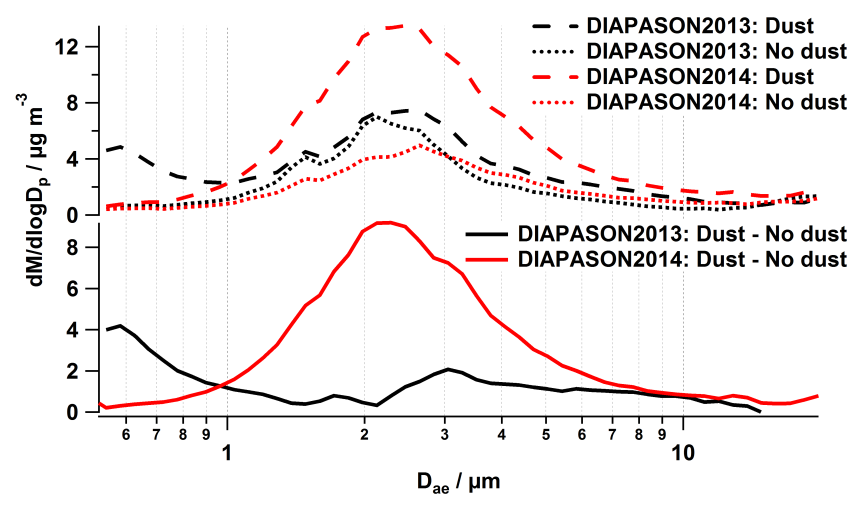

Figure 3. Size-resolved mass distribution $\left(\mathrm{d} M / \mathrm{d} \log D_{\mathrm{p}}\right)$ during dust (dashed traces) and no dust (dotted traces) periods (top panel) measured with the APS during DIAPASON2013 (black traces) and DIAPASON2014 (red traces). The difference of the size-resolved mass distributions measured during dust and no dust periods indicate the size distributions of the dust particles measured during both years (bottom panel). $D_{\mathrm{ae}}$ is the aerodynamic particle diameter.

1.4 in central Rome. As discussed above, changes in meteorological conditions are likely one explanation for this result: during DIAPASON2013 meteorological conditions favoured the accumulation of pollutants, whereas the dilution of pollutants was favoured during the POPE2013 measurement period. During DIAPASON2014 and POPE2014, TKE and BLH were rather similar, leading to comparable pollutant dilution effects during the two measurement periods. BLH was higher by around $75 \%$ in May/June compared to October/November 2013, leading to stronger dilution capacities in general. In addition to meteorological conditions (e.g. solar radiation, BLH, TKE, air mass origin), local air quality can be strongly influenced by local emissions from various sources (traffic, cooking, biomass burning). A strong influence of meteorological conditions (air mass origin) on air quality was also observed during the MEGAPOLI campaign in Paris in July 2009, when variations in secondary aerosol concentration were mainly attributed to such factors (Freutel et al., 2013).

\subsection{Aerosol sources: identification and characterization}

In this section the various aerosol types and sources which were identified from the data obtained during the DIAPASON and POPE measurement campaigns in 2013 and 2014 are discussed in more detail. Each identified aerosol type was characterized in an attempt to determine its contribution to total particulate mass and its seasonal and spatial variability. Furthermore, the potential origin of the identified aerosol types is discussed.

\subsubsection{Saharan dust}

During each DIAPASON field campaign one dust advection event lasting for several days was observed. The identification of the dust events with dust reaching down to the ground was based on dust forecasts provided by the SKIRON model (Kallos et al., 1997) and on co-located polarization lidar-ceilometer measurements (data can be found at www.diapason-life.eu). A PIXE analysis of $1 \mathrm{~h}$ filter samples confirmed a significant increase of mineral dust concentrations (i.e. $\mathrm{Na}, \mathrm{Mg}, \mathrm{Si}, \mathrm{Al}, \mathrm{Ti}, \mathrm{K}, \mathrm{Ca}, \mathrm{Fe}$; Nava et al., 2012) at ground level during the identified dust periods (Barnaba et al., 2016). Table 5 provides the time intervals of "dust" and "no dust" periods (i.e. background with respect to dust advections) for DIAPASON2013 and DIAPASON2014. Based on these, estimations regarding the contribution of dust to PM levels were made by calculating the coarse particle fraction $\left(\mathrm{PM}_{10-2.5}\right)$ from EDM measurements for the respective periods (Table 5).

During DIAPASON2013, a Saharan dust advection period was observed from the beginning of the measurements (23 October) to 1 November with $\mathrm{PM}_{10-2.5}$ concentrations at ground level being increased by $80 \%$ with respect to background conditions. Total $\mathrm{PM}_{10}$ concentrations were elevated by $150 \%$, with 71 and $57 \%$ of the mass belonging to $\mathrm{PM}_{1}$ during the dust event and background periods, respectively. This increase in absolute $\mathrm{PM}_{1}$ with an increase in the fraction of $\mathrm{PM}_{1}$ during the dust advection compared to background conditions was also reflected in the particle size distributions (Fig. 3, black traces). The dust event was forecasted by the BSC-DREAM8b model (Basart et al., 2012; Perez et al., 2006a, b), and HYSPLIT (Stein et al., 2015) back trajectories showed dust transport from the Sahara with main dust sources located at $30-33^{\circ} \mathrm{N}$, between Morocco (Saharan Atlas) and SW Tunisia (Erg Oriental), in the period 26-28 October 2013, moving along an anticyclonic pattern.

During DIAPASON2014 a dust event was observed from 20 (13:00) to 26 May (09:00). Here, the coarse particle fraction $\left(\mathrm{PM}_{10-2.5}\right)$ increased by $180 \%$ compared to the no dust interval with much smaller fractions of particle mass in $\mathrm{PM}_{1}$ (31 and $48 \%$ in the dust and no dust periods, respectively). The contribution of dust to the coarse particle fraction with almost no contribution to the submicron fraction is reflected in the difference particle mass size distribution (Fig. 3, bottom panel, red trace), which shows maximum mass concentrations for aerodynamic particle diameters around $2 \mu \mathrm{m}$ and smaller contributions extending down to $\sim 600 \mathrm{~nm}$ and up to more than $10 \mu \mathrm{m}$ particle diameter. Comparing both dust events in terms of particle size, the contribution of the dust advection event during DIAPASON2014 was characterized by a broad particle mass size distribution with maximum concentrations at particle sizes around $2 \mu \mathrm{m}$, whereas in 2013 two modes (with maxima around 0.6 and $3 \mu \mathrm{m}$ ) were observed. Both the BSC-DREAM8b model and HYSPLIT back trajectories showed dust transport from the Sahara to occur 
Table 5. Summary of dust and no dust periods identified during DIAPASON2013 and DIAPASON2014, including mean values and standard deviation of $\mathrm{PM}_{10-2.5}, \mathrm{PM}_{10}$ and $\mathrm{PM}_{1}$ (all from EDM measurements).

\begin{tabular}{|c|c|c|c|c|}
\hline & \multicolumn{2}{|c|}{ DIAPASON2013 } & \multicolumn{2}{|c|}{ DIAPASON2014 } \\
\hline & Dust & No dust & Dust & No dust \\
\hline Period & 23.10.-01.11.13 & 02.11.-07.11.13 & 20.05.-26.05.14 & 27.05.-04.06.14 \\
\hline Mean $\mathrm{PM}_{10-2.5}\left(\mu \mathrm{g} \mathrm{m}^{-3}\right)$ & $5.4 \pm 3.1$ & $3.0 \pm 2.5$ & $15.4 \pm 5.9$ & $5.5 \pm 2.8$ \\
\hline Mean $\mathrm{PM}_{10}\left(\mu \mathrm{g} \mathrm{m}^{-3}\right)$ & $28 \pm 10$ & $11 \pm 6$ & $22 \pm 7$ & $11 \pm 5$ \\
\hline \multirow[t]{2}{*}{ Mean $\mathrm{PM}_{1}\left(\mu \mathrm{g} \mathrm{m}^{-3}\right)$} & $20 \pm 9$ & $6.3 \pm 4.1$ & $7.0 \pm 3.3$ & $5.0 \pm 3.5$ \\
\hline & $\left(71 \%\right.$ of $\left.\mathrm{PM}_{10}\right)$ & $\left(57 \%\right.$ of $\left.\mathrm{PM}_{10}\right)$ & $\left(32 \%\right.$ of $\left.\mathrm{PM}_{10}\right)$ & $\left(45 \%\right.$ of $\left.\mathrm{PM}_{10}\right)$ \\
\hline
\end{tabular}
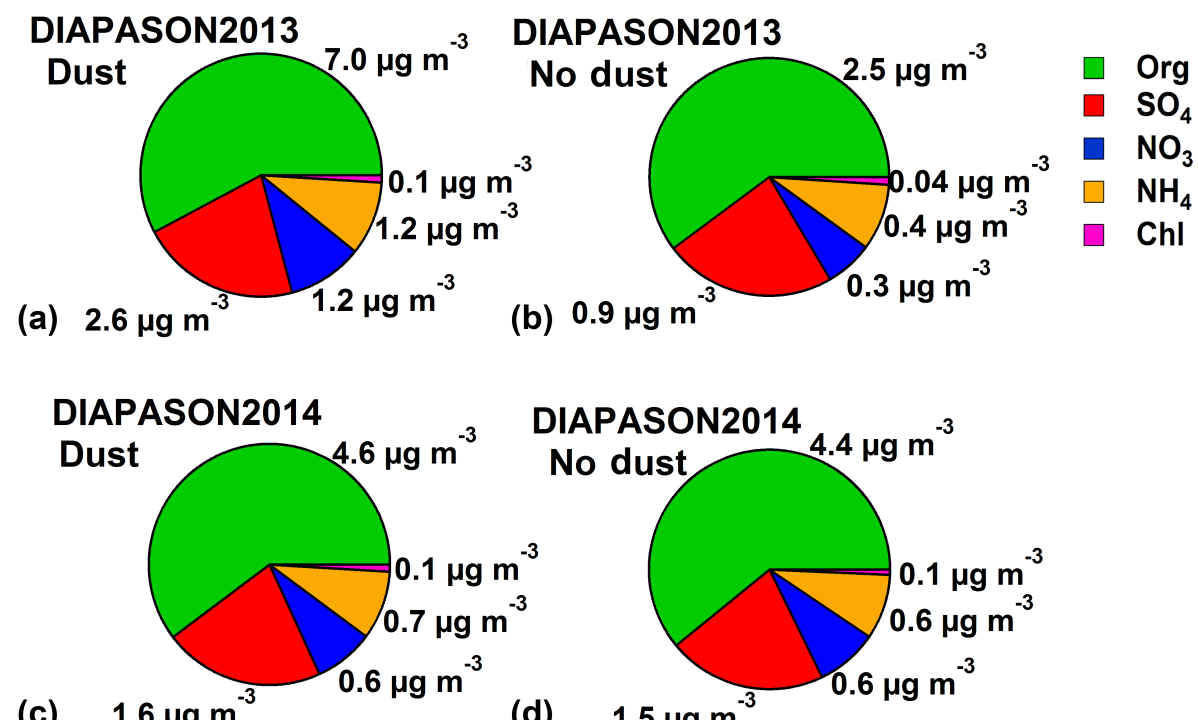

(c)

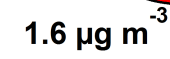

(d)
$1.5 \mu \mathrm{g} \mathrm{m}^{-3}$

Figure 4. Comparison of mean chemical composition of non-refractory $\mathrm{PM}_{1}$ obtained from AMS measurements during dust (left) and no dust (right) periods during DIAPASON2013 (top) and DIAPASON2014 (bottom).

between 19 and 22 May 2014 along a cyclonic pattern, with dust originating (as in October 2013) at $30-35^{\circ} \mathrm{N}$ between Morocco (Saharan Atlas) and SW Tunisia (Erg Oriental).

With regard to the coarse particle mode $\left(\mathrm{PM}_{10-2.5}\right)$ the dust event during DIAPASON2014 was more distinct. In terms of absolute $\mathrm{PM}_{10}$ concentrations, higher concentrations at ground level were reached during the dust advection measured during DIAPASON2013. However, with respect to the no dust conditions, mean $\mathrm{PM}_{10}$ increases of about 17 and $11 \mathrm{\mu g} \mathrm{m}^{-3}$ were observed during DIAPASON2013 and DIAPASON2014, respectively. This agrees well with the observations made by Gobbi et al. (2013), who reported $\mathrm{PM}_{10}$ concentrations in the order of $12-16 \mu \mathrm{g} \mathrm{m}^{-3}$ during dust advection events in the period 2001-2004. During both advection events legal $\mathrm{PM}_{10}$ limits of the European Union (daily mean value of $50 \mu \mathrm{g} \mathrm{m}^{-3}$ ) were not exceeded.

AMS data were investigated for potential impacts of Saharan dust advections on the chemical composition of nonrefractory submicron particles. Figure 4 presents the mean chemical composition of non-refractory $\mathrm{PM}_{1}$ measured dur- ing dust and no dust periods for both DIAPASON campaigns. Only in 2013 differences in absolute mass concentrations were observed, consistent with higher submicron particle concentrations observed in the mass size distributions during this dust event (Fig. 3, bottom panel, black trace). This difference in $\mathrm{PM}_{1}$ concentration between the dust and no dust period is likely due to differences in air mass origin. Whereas during the dust period air masses preferentially arrived from the Mediterranean region, the no dust period was mainly influenced by air masses from the Atlantic Ocean. However, the relative composition remains nearly the same for both periods in both years. This result suggests that there was no significant influence of the dust advection on the chemical composition of the submicron non-refractory aerosol fraction.

In order to cross-check whether differences in meteorological conditions could have biased these results, and, for example, could have compensated for changes due to the dust affecting non-refractory $\mathrm{PM}_{1}$, averages of meteorological variables were calculated for dust and no dust periods. The 

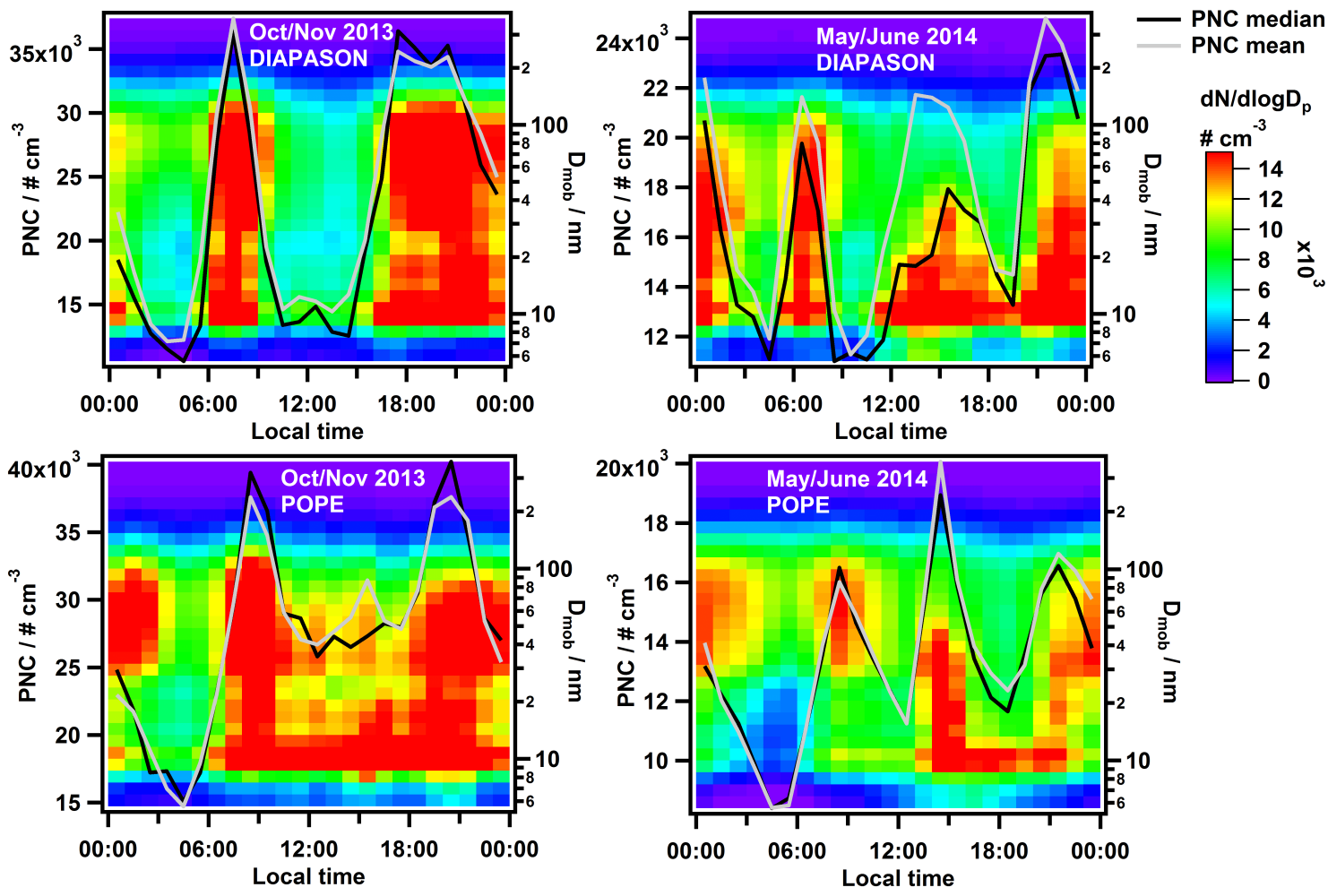

Figure 5. Average diurnal cycles of particle number concentrations and size distributions for DIAPASON (top) and POPE (bottom) for each year (left: 2013, right: 2014). Image plots of diurnal cycles of the particle number size distributions (colour coded for $\left.\mathrm{d} N / \mathrm{dlog} D_{\mathrm{p}}\right)$ are shown with the particle diameters on the right axes (mobility particle diameter $D_{\text {mob }}$ ). Mean (grey) and median (black) diurnal cycles of the total particle number concentrations are shown on the left axes. New particle formation at midday was only observed in the May/June 2014 campaigns.

only slight differences found between dust events and background conditions were in local wind directions (SE compared to $S$ in 2013, and SW compared to SSW in 2014) and in wind speeds $\left(1.5 \pm 0.8 \mathrm{~m} \mathrm{~s}^{-1}\right.$ compared to $2.7 \pm 1.6 \mathrm{~m} \mathrm{~s}^{-1}$ in 2013). Since these differences are only very minor, we conclude that our observation of comparable chemical composition of non-refractory $\mathrm{PM}_{1}$ during dust and no dust periods was not caused by any compensating effects.

\subsubsection{Secondary and aged aerosol: seasonal influence on formation processes and chemical composition}

Seasonal variations of the characteristics of secondary and aged aerosols were identified by investigating new particle formation events and particle chemical composition measured during both POPE and DIAPASON campaigns in October/November 2013 and May/June 2014.

\section{New particle formation}

Diurnal cycles of size-resolved and total particle number concentrations (PNCs) for the October/November 2013 and May/June 2014 campaigns (Fig. 5) revealed several seasonal differences. During measurements in October/November
2013 (Fig. 5, left panels), elevated PNCs were only observed during rush hour times in the morning and the evening, whereas in the measurements in May/June 2014, an additional PNC peak occurred with maxima around 13:00-15:00 (DIAPASON2014) and 14:00-15:00 (POPE2014) (Fig. 5, right panels). At the urban site (Fig. 5, bottom panels), PNCs after the morning rush hour remain at an elevated level, likely because of increased background concentrations due to generally higher traffic density in the city centre. PNCs were generally higher in the October/November 2013 than in the May/June 2014 campaigns, as discussed in Sect. 4.1.

Mean particle number size distributions for the period of maximum PNC at midday (Fig. 6; nucleation; solid traces) show a distinct mode at small particle diameters between 7 and $15 \mathrm{~nm}$ for the May/June 2014 campaigns (visible in Fig. 5, right panels) compared to the number size distribution measured between 10:00 and 11:00 (Fig. 6; background; dashed traces). Such occurrences of ultrafine particles at midday, when concentrations of particles from traffic are at a relative minimum, thus are not responsible for strongly increased PNC, have been attributed before to new particle formation characteristic for urban areas with high solar radiation (Brines et al., 2015; Minguillon et al., 2015; Reche et 
Table 6. Variables measured during DIAPASON2014 indicating different ambient conditions on days classified as nucleation, non-defined and non-nucleation days. Total particle number concentrations (PNCs) and the classification criteria and number of respectively classified days are also listed. For each measurement day and presented variable, daily averages for the period 10:00-16:00 were calculated. Here, the mean and standard deviation of these averages are shown with maximum values in bold and minimum values in italic.

\begin{tabular}{|c|c|c|c|}
\hline & Nucleation days & Non-defined days & Non-nucleation days \\
\hline Classification & $\mathrm{PNC}_{\text {nuc }} / \mathrm{PNC}_{\mathrm{bg}} \geq 1.5$ & $1<\mathrm{PNC}_{\text {nuc }} / \mathrm{PNC}_{\mathrm{bg}}<1.5$ & $\mathrm{PNC}_{\text {nuc }} / \mathrm{PNC}_{\mathrm{bg}} \leq 1$ \\
\hline Number of days & 6 & 6 & 2 \\
\hline Rain* (mm) & $O(0)$ & $0.7(1)$ & $2.3(1)$ \\
\hline Total PNC $\left(10^{3} \mathrm{~cm}^{-3}\right)$ & $25 \pm 9$ & $13 \pm 3$ & $12 \pm 1$ \\
\hline Temperature $\left({ }^{\circ} \mathrm{C}\right)$ & $23 \pm 2$ & $22 \pm 2$ & $20 \pm 0$ \\
\hline Rel. humidity (\%) & $43 \pm 6$ & $46 \pm 9$ & $56 \pm 4$ \\
\hline Solar radiation $\left(\mathrm{W} \mathrm{m}^{-2}\right)$ & $780 \pm 80$ & $700 \pm 190$ & $670 \pm 200$ \\
\hline $\mathrm{O}_{3}(\mathrm{ppb})$ & $54 \pm 4$ & $47 \pm 6$ & $48 \pm 1$ \\
\hline Total $\mathrm{PM}_{1}$ organics $\left(\mu \mathrm{g} \mathrm{m}^{-3}\right)$ & $3.9 \pm 2.4$ & $3.6 \pm 1.0$ & $2.9 \pm 2.3$ \\
\hline
\end{tabular}

* Total accumulated amount of rain (10:00-16:00). Numbers of days with rain are given in parentheses.

\section{New particle formation}

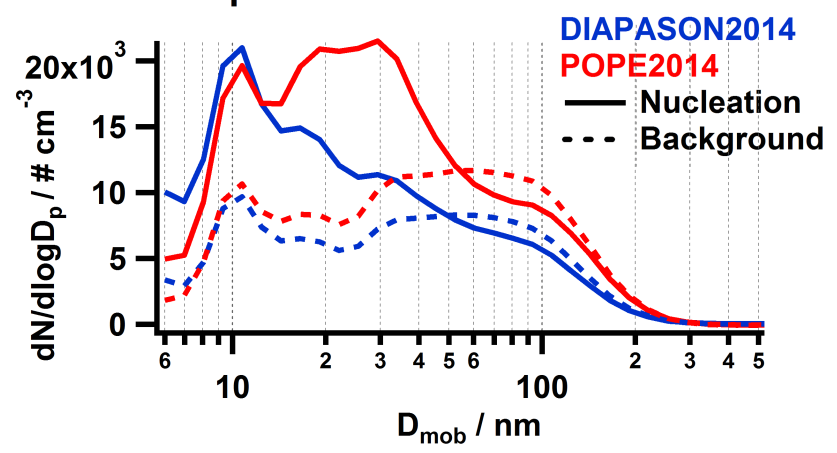

Figure 6. Average size distributions of particle number concentrations $\left(\mathrm{dN} / \mathrm{d} \log D_{\mathrm{p}}\right)$ for maximum PNC at midday (DIAPASON2014: 13:00-15:00; POPE2014: 14:00-15:00; solid traces) and during background conditions (10:00-11:00; dashed traces) from FMPS measurements for DIAPASON2014 (blue) and POPE2014 (red). $D_{\mathrm{mob}}$ is the mobility diameter.

al., 2011). During POPE2014 an additional mode at larger particle sizes ( $D_{\mathrm{p}}$ approximately $\left.15-50 \mathrm{~nm}\right)$ was found in the particle size distribution measured at midday (Fig. 6), probably originating from increased background levels.

During POPE2014 diurnal cycles of mean (grey) and median (black) PNCs agree very well with each other, even during the midday peak (Fig. 5). This reflects the observed low day-to-day variability during this period for the measurements in central Rome, wherein the corresponding PNC time series a midday peak was observed every single day. Local smoking activities (see Sect. 4.2.5) at the central Rome measurement location did not seem to have biased these results, since no differences in diurnal cycles of PNC for weekdays (smoking activities) and weekends (no smoking activities) have been found. This suggests that the formation of new particles around midday was taking place every day in central Rome during the May/June 2014 measurement period.
Conversely, the diurnal cycle of total PNC measured during DIAPASON2014 shows a clear discrepancy between mean and median values during the midday peak (Fig. 5). This discrepancy is due to the fact that new particle formation events did not occur on all days, probably induced by different meteorological conditions and/or differences in preexisting particle surface areas (e.g. Kulmala and Kerminen, 2008).

To test whether particular meteorological conditions can promote/suppress new particle formation events, nucleation and non-nucleation days were classified for DIAPASON2014 by comparing PNCs measured during 10:0011:00 (background conditions, $\mathrm{PNC}_{\mathrm{bg}}$ ) and 11:00-16:00 (typical nucleation periods, $\mathrm{PNC}_{\text {nuc }}$; Table 6). This classification was cross-checked by verifying whether during classified nucleation days a clear increase in PNC at small particle diameters $\left(D_{\mathrm{p}} \leq 25 \mathrm{~nm}\right)$ could be observed in the particle number size distributions, and whether it was missing on classified non-nucleation days. Only one potentially falsely classified nucleation day (24 May 2014) was found by checking these criteria and was moved to the class of non-defined days. The classification resulted in 6 nucleation days, 6 nondefined days and 2 non-nucleation days.

Mean values for the time period 10:00 to 16:00 (new particle formation period plus one previous hour) were calculated for each day and averaged according to the above-mentioned classification for the DIAPASON2014 campaign. Table 6 lists PNCs of the classified periods and variables potentially supporting new particle formation. A slight trend of increased temperature, solar radiation and ozone levels and low relative humidity characterizes nucleation days compared to non-nucleation days and non-defined days. This is consistent with previously reported associations between high solar radiation (Pikridas et al., 2015; Shi et al., 2001), low relative humidity (Kulmala and Kerminen, 2008) and increased ozone concentrations (Harrison et al., 2000) with new par- 
ticle formation events. No relationship between the occurrence of new particle formation and the presence of Saharan dust was observed. In contrast to the findings of Zhang et al. (2004), no increase of sulfate, ammonium and nitrate concentrations was observed in our measurements during periods with new particle formation events. Estimations based on the size distribution measurements during DIAPASON2014 reveal that less than $1 \%$ of $\mathrm{PM}_{1}$ can be assigned to particles generated by new particle formation. Therefore, it is not surprising that no significant influence of the particle formation events on the AMS-measured chemical particle composition could be observed.

In summary, our data do not provide sufficient statistical evidence to unequivocally determine the driving factors of new particle formation. However, since such indications were only observed in the warmer season at both locations, they are probably linked to higher temperatures and stronger solar radiation. Similar results were obtained from the MEGAPOLI measurements in Paris, where new particle formation was only observed during summer (Pikridas et al., 2015). During the May/June 2014 campaigns, new particle formation events occurred on roughly $43 \%$ of the measurement days at the suburban location, but on each single day in central Rome, potentially due to increased concentrations of precursors and higher prevailing mean temperatures (Table 3). In a long-term measurement study carried out by Costabile et al. (2010), the occurrence of aged nucleation mode particles (up to $30 \mathrm{~nm}$ ) was observed predominantly in spring in the area of Rome at a regional background site (located more remotely than the Tor Vergata site) in the early afternoon (15:00) when the measurement site was located downwind of Rome (Brines et al., 2015). In contrast, during DIAPASON2014 measurements, no dependency between nucleation events and wind direction was observed, and the site was not located downwind of Rome during nucleation periods. At this measurement location, concentrations of precursors are probably lower than in central Rome; however, they are higher than at a remote background site such as in the study by Costabile et al. (2010). This probably facilitates new particle formation events in the direct vicinity of the site under favourable meteorological conditions, but independent of advection of air masses from central Rome.

\section{Secondary and aged aerosol}

Because of extremely low mass contributions from freshly formed particles to total particle mass, new particle formation had no influence on the measured total organics mass concentrations. However, a general seasonal difference in the composition of the oxygenated organic aerosol (OOA) as determined in the PMF analysis was found, as discussed in the following.

OOA, an aerosol type with increased oxygenation level, typically dominates the OA fraction. It is assumed to be mainly formed in the atmosphere from gaseous biogenic

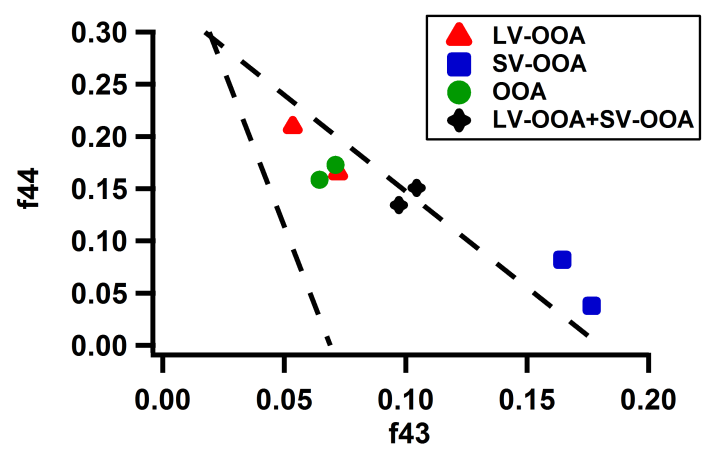

Figure 7. f44 vs. f43 plotted for each OOA factor obtained from PMF analysis of the organic fraction of HR-AMS data. OOA factors (green markers) resulted from DIAPASON2013 and POPE2013 measurements; SV-OOA (blue markers) and LV-OOA factors (red markers) were found during DIAPASON2014 and POPE2014 measurements. The recombination of the factors LV-OOA and SV-OOA for both DIAPASON2014 and POPE2014 is also shown (black markers). The dashed lines represent the triangular space in which measured ambient OOA components typically cluster according to $\mathrm{Ng}$ et al. (2010).

and anthropogenic precursors by photochemical oxidation, thus indicating SOA. Additionally, some OOA may originate from atmospheric aging of POA. Generally, aging processes are reflected in an increased degree of aerosol oxidation (Jimenez et al., 2009), leading to a larger fraction of $\mathrm{m} / z 44\left(\mathrm{CO}_{2}^{+}\right)$in the aerosol mass spectra, generated by thermal decomposition of carboxylic acids in the AMS (Alfarra et al., 2004). Additionally, a prominent peak in OOA mass spectra occurs at $m / z 43\left(\mathrm{C}_{3} \mathrm{H}_{7}^{+}\right.$and $\left.\mathrm{C}_{2} \mathrm{H}_{3} \mathrm{O}^{+}\right)$. Under conditions for which sufficient freshly oxidized organic aerosol is available in the ambient air, PMF can separate the OOA into two factors. These factors differ in their relative fractions of $m / z 44$ and $m / z 43$ ( $f 44$ and $\mathrm{f} 43$, ratio of $m / z 44$ and $m / z 43$ signal, respectively, to the total signal of organics), which reflects their different degrees of oxidation. The factor associated with higher $\mathrm{f} 43$ indicates a less oxidized, fresher, more locally produced semi-volatile OA (SV-OOA), whereas a higher $\mathrm{f} 44$ indicates a stronger oxidized, more aged lowvolatile OA (LV-OOA; Ng et al., 2010).

During our measurements the relative contribution of OOA to total organics varied between 42 and $76 \%$, with slightly higher contributions during the warm period (Fig. 2). However, the main seasonal difference was found in the composition of the OOA fraction. During the October/November 2013 campaign only one type of OOA was found, whereas for May/June 2014 PMF analysis resulted in two OOAfactors, SV-OOA and LV-OOA. This is typically only observed during summer conditions, when the dynamic range of temperature, ozone concentration and solar radiation is large, which is assumed to be the main driving force for the variability of the OOA volatilities (Jimenez et al., 2009). Similar observations were made during the MEGAPOLI 
measurements in Paris, where only one factor describing OOA was identified in winter (Crippa et al., 2013a), whereas during summer SV-OOA and LV-OOA could be separated (Crippa et al., 2013b).

The ratio of $\mathrm{f} 44$ to $\mathrm{f} 43$ gives an indication of the mean aging level of the aerosol (Fig. 7; Ng et al., 2010). LVOOA (from DIAPASON2014 and POPE2014, red markers) and OOA (from DIAPASON2013 and POPE2013, green markers) fall into the same region in the $\mathrm{f} 44 \mathrm{vs}$. $\mathrm{f} 43$ plot (Fig. 7), indicating similar aging stages. SV-OOA (from DIAPASON2014 and POPE2014, blue markers) shows a much higher fraction of $m / z 43$ together with a decreased $m / z 44$ fraction, which suggests a low-oxidized, less aged particle type. The recombined LV-OOA+SV-OOA (black markers in Fig. 7) shows a stronger contribution of $\mathrm{f} 43$ compared to OOA, indicating an overall higher fraction of less oxidized organic aerosol in the warmer season. We assume that LVOOA (and OOA) is mainly advected and consists of strongly processed material, whereas the low oxidation level of SVOOA suggests a fresh, more locally produced aerosol which was quickly formed from regional precursors as a consequence of increased photochemistry during this season.

This hypothesis is tested by the use of polar plots, which connect species concentration with information on local wind direction and speed, thereby indicating the origin of a certain type of aerosol (see Sect. 3.1). Figure 8a shows the colour-coded concentration of SV-OOA, $\mathrm{LV}-\mathrm{OOA}, \mathrm{NH}_{4}$, $\mathrm{NO}_{3}$ and $\mathrm{SO}_{4}$ depending on wind direction and speed obtained during the DIAPASON2014 measurements. SV-OOA concentrations are increased during low wind speed conditions, indicating nearby, no-buoyance sources. In contrast, LV-OOA concentrations are almost independent of wind speed with only slightly increased concentrations during periods of high wind speed with mainly south-westerly wind directions (direction of the Tyrrhenian Sea). This suggests that LV-OOA is not associated with sources located in the vicinity of the measurement site, but long-range transported to the site, e.g. over the ocean or from central Europe. The polar plot characteristics of $\mathrm{NO}_{3}$, which is often used as a tracer for semi-volatile aerosol (DeCarlo et al., 2010; Lanz et al., 2007), show strong similarities to the ones of SV-OOA (Fig. 8a). Furthermore, $\mathrm{SO}_{4}$ and LV-OOA show polar plot patterns similar to each other (Fig. 8a), confirming the characteristics of an aged, regionally transported aerosol. The polar plot of $\mathrm{NH}_{4}$ shows a hotspot at low wind speeds in a northerly direction, which is also reflected in the patterns of SV-OOA and $\mathrm{NO}_{3}$. Increased $\mathrm{NH}_{4}$ concentrations are also observed at higher wind speeds with south-westerly wind directions, agreeing with the polar plot patterns of LV-OOA and $\mathrm{SO}_{4}$.

The polar plot of OOA obtained for DIAPASON2013 shows increased concentrations, particularly during periods of north-easterly, but also south-westerly, wind directions (Fig. 8b). During conditions of low wind speed, OOA concentrations are increased independently of the prevail- ing wind direction. In contrast to the findings for DIAPASON2014, for this data set similar polar plot characteristics as for OOA were observed partly in the plots of $\mathrm{NO}_{3}$, $\mathrm{NH}_{4}$ and $\mathrm{SO}_{4}$ (Fig. 8b). Elevated $\mathrm{NH}_{4}$ and $\mathrm{SO}_{4}$ concentrations were mainly measured during times with southwesterly wind directions, whereas for $\mathrm{NO}_{3}$ an increase for north-easterly directions was observed. Based on the polar plot characteristics no consistent trend indicating the degree of aging, the source or the formation process of the OOA fraction can be observed, consistent with the assumption of advection of a rather aged type of OOA together with different amounts of $\mathrm{NO}_{3}, \mathrm{SO}_{4}$ and $\mathrm{NH}_{4}$, depending on air mass history.

\subsubsection{Particles from biomass burning}

The type of primary organic aerosol at Tor Vergata identified from PMF analysis, which had the largest share during both measurement periods, was attributed to biomass burning (biomass burning OA, BBOA). BBOA was identified by comparison with the time series of known ion fragments of levoglucosan $\left(\mathrm{C}_{3} \mathrm{H}_{5} \mathrm{O}_{2}^{+}(\mathrm{m} / \mathrm{z} 73)\right.$ and $\mathrm{C}_{2} \mathrm{H}_{4} \mathrm{O}_{2}^{+}(\mathrm{m} / \mathrm{z} 60)$; Schneider et al., 2006) and by correlating the BBOA mass spectra with those presented by Mohr et al. (2012). With Pearson's $R^{2}=0.57-0.59$ rather poor correlations were obtained, which demonstrates the complexity and the potential variations of the BBOA mass spectra due to aging processes and differences in source processes (e.g. different burning conditions or fuels; Weimer et al., 2008). The mean BBOA mass concentration was $1.28 \mu \mathrm{g} \mathrm{m}^{-3}$ (24\% of total OA) in October/November 2013 and $0.82 \mu \mathrm{g} \mathrm{m}^{-3}$ (18\% of total OA) in May/June 2014, respectively (Fig. 2). Increased BBOA concentrations during the colder season probably result from stronger agricultural burning activities (green waste burning) and potentially domestic heating, as well as from lower boundary layer heights. However, due to the moderate temperatures during the October/November 2013 measurements, we do not expect strong contributions from domestic heating. In the evening of 25 October 2013 during a strong, visually detectable biomass burning event, which could be related to green waste burning in the nearby Alban Hills, maximum concentrations of BBOA were obtained (up to $75 \mu \mathrm{g} \mathrm{m}^{-3}$ ). This event was used during the identification of the PMF solution, since only a PMF factor showing a concentration increase during the period of this event could be considered to be attributed to biomass burning emissions.

The origin of BBOA emissions was further investigated by relating BBOA mass concentrations to local wind direction and speed (see Sect. 3.1). The resulting polar plots (Fig. 9) indicate BBOA particles mainly arriving from south-easterly directions during DIAPASON2013. During this measurement period agricultural fires were frequently observed in the Alban Hills (Frascati vineyard area), which are located in this direction. Additionally, BBOA was observed during conditions of north-easterly winds and higher wind speeds (up to 


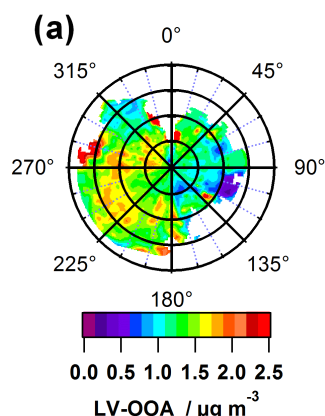

(b)

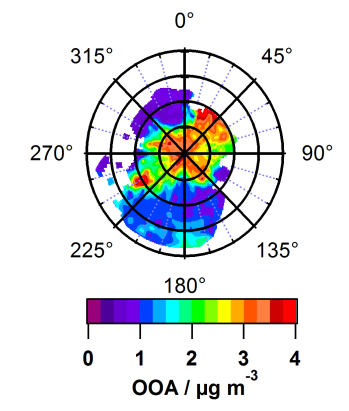

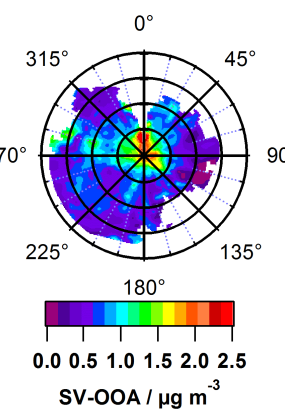
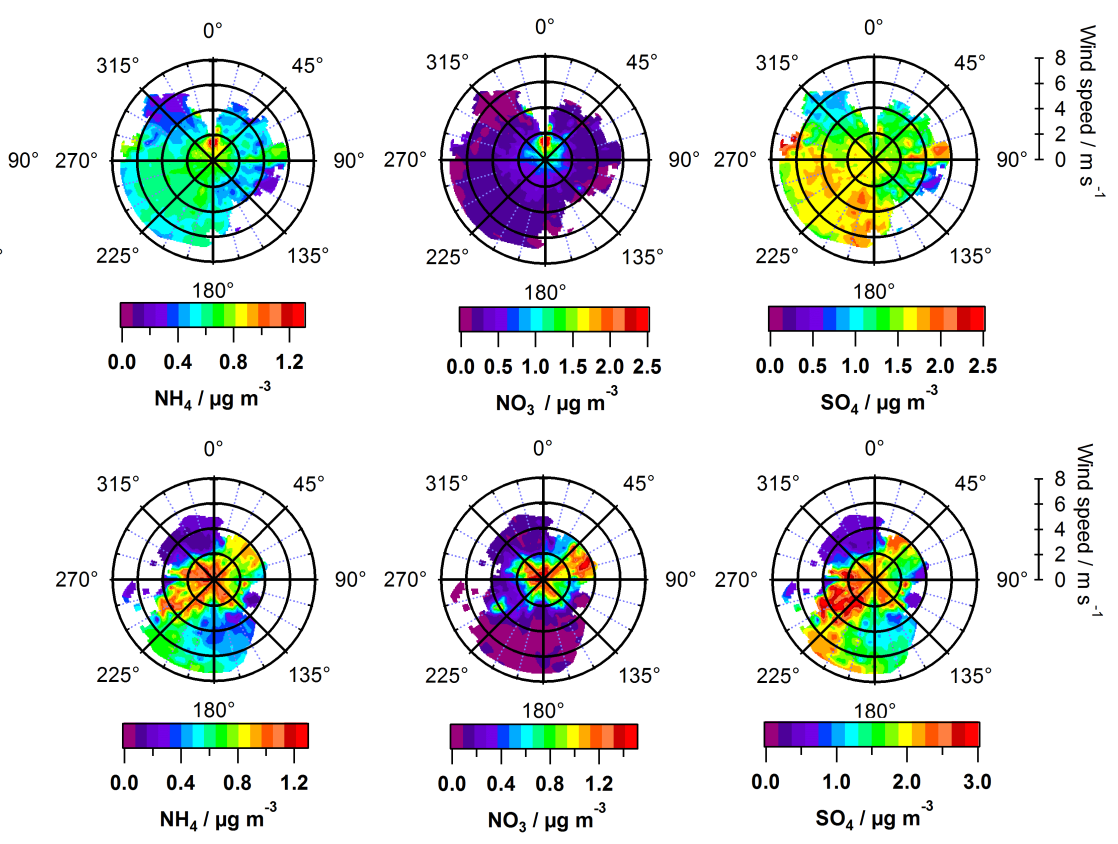

Figure 8. Polar plots of (a) submicron LV-OOA, SV-OOA, $\mathrm{NH}_{4}, \mathrm{NO}_{3}$ and $\mathrm{SO}_{4}$ concentration (colour coded) obtained from DIAPASON2014 measurements and (b) submicron $\mathrm{OOA}, \mathrm{NH}_{4}, \mathrm{NO}_{3}$ and $\mathrm{SO}_{4}$ concentration obtained from DIAPASON2013 measurements as a function of local wind direction $\left(^{\circ}\right)$ and speed $\left(\mathrm{m} \mathrm{s}^{-1}\right)$.

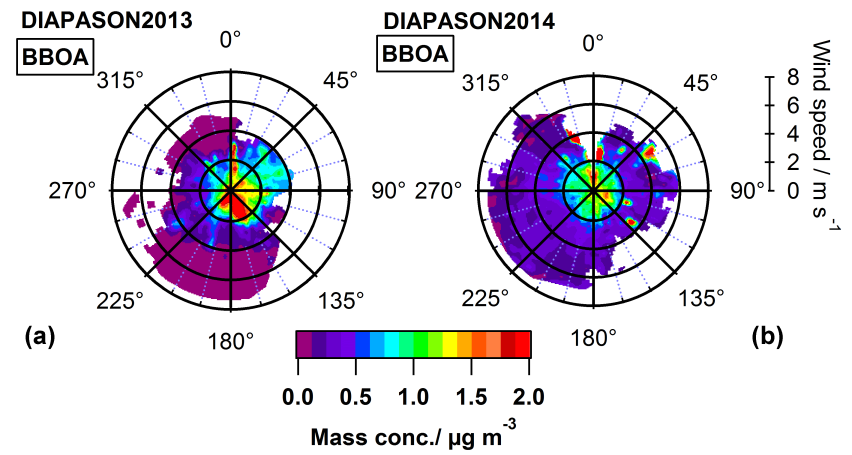

Figure 9. Submicron BBOA mass concentrations (colour coded) as a function of local wind direction $\left(^{\circ}\right)$ and speed $\left(\mathrm{m} \mathrm{s}^{-1}\right)$ for DIAPASON2013 (left) and DIAPASON2014 (right).

$4 \mathrm{~m} \mathrm{~s}^{-1}$ ), possibly resulting from residential wood burning in a densely populated urban periphery area (Borghesiana). The polar plot of BBOA obtained from DIAPASON2014 measurements hardly points to any preferential direction of BBOA origin. Since elevated BBOA concentrations were mainly reached during low wind speed conditions, emissions from rather local sources is suggested.

BBOA was not identified in the measurements in the city centre of Rome, even not in PMF solutions with a large number of factors (8). Since green-waste burning and domestic heating with biomass are forbidden in central Rome, biomass-burning-related particles are probably not emitted in the local environment. However, the contribution of biomass burning and domestic heating to the urban air pollution of Rome (especially during wintertime) was reported by Gariazzo et al. (2016). Apparently, during our measurements in late spring and autumn the contribution of particles emitted outside the suburban area is too small to be identified with PMF and/or aging processes during the transport of the particles lead to a loss of the BBOA fingerprint (Bougiatioti et al., 2014). Furthermore, during the MEGAPOLI measurements in Paris, emissions from biomass burning were identified in the organic aerosol fraction (Crippa et al., 2013a). In contrast to our measurements, in Paris, BBOA was only found during the wintertime campaign (January/February) and was also found at the measurement location in the city centre, probably generated by local domestic wood burning (Crippa et al., 2013a).

In summary, the results from both DIAPASON measurements show that particles from biomass burning significantly (18-24\% of total OA) contributed to local air pollution in the suburban area in late autumn as well as in late spring. Agricultural fires and possibly wildfires are probably their most important sources, since heating activities are assumed to be quite low at these times due to the moderate temperature conditions (Table 3). 


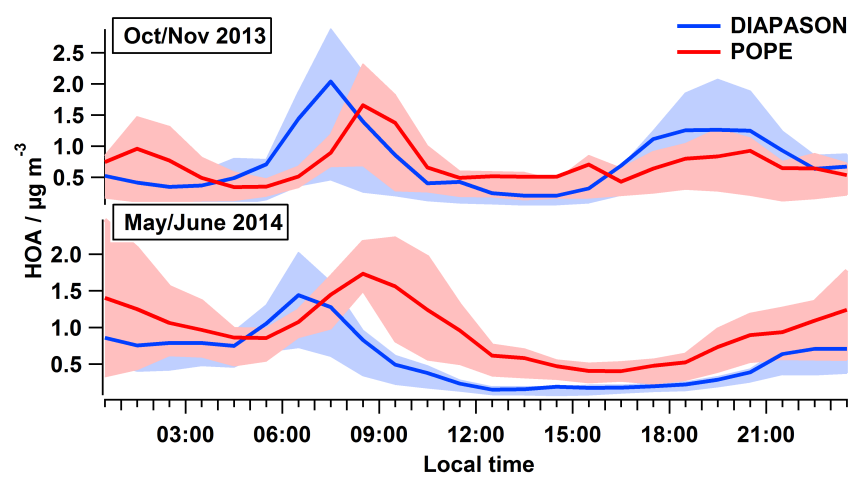

Figure 10. Diurnal cycles of HOA mass concentrations obtained from measurements at Tor Vergata (blue: DIAPASON) and central Rome (red: POPE) during both seasons. Mean concentrations (traces) and the corresponding 25th and 75th percentiles (shaded areas) are shown.

\subsubsection{Emissions related to traffic and cooking activities}

At both measurement locations, during both seasons particles from traffic-related as well as cooking-related emissions were detected.

Indications of traffic-related emissions can be found in several measured variables showing a distinct diurnal pattern with peaks during the morning and evening rush hours. The time series and diurnal pattern of HOA (hydrocarbon-like organic aerosol), a PMF factor that is typically associated with traffic emissions, show good agreement with the respective patterns of species like $\mathrm{BC}, \mathrm{NO}_{x}$ and $\mathrm{PAH}$ (diurnal cycles $R^{2}>0.85$ ) for all four campaigns. Correlations of complete campaign time series of HOA with BC result in good agreements $\left(R^{2} \approx 0.7\right)$.

In the diurnal cycles of HOA, seasonal and spatial differences can be observed (Fig. 10). Independent of season and measurement location, a short peak occurs during the morning rush hour and a broader peak starts during the evening rush hour. During all field campaigns except DIAPASON2013, HOA concentrations remain high throughout the night. Thus, the exact period of the evening rush hour cannot be clearly isolated. These differences in the forms of the HOA peaks in the morning and evening rush hour are mainly controlled by boundary layer dynamics together with the diurnal cycle of traffic-related emissions (rush hour times). A seasonal difference is observed in the HOA evening rush hour peak, which occurs around midnight in May/June but around 19:00-20:00 in October/November. This shift and the broadening of the HOA peak in May/June 2014 is probably driven by the different boundary layer dynamics during the two seasons.

For both measurement years a time shift of the morning peak between Tor Vergata and central Rome (later by about one hour) can be observed. Since similar diurnal temperature profiles measured at the suburban and the urban loca-

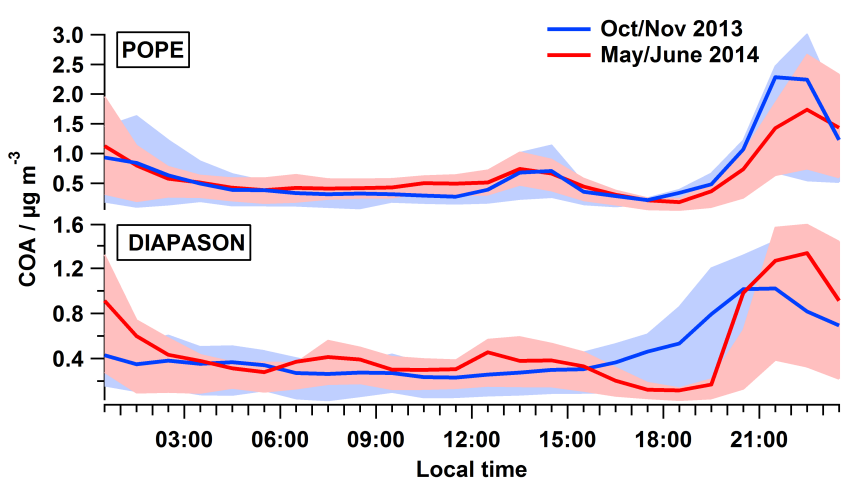

Figure 11. Diurnal cycles of COA mass concentrations observed in central Rome (top: POPE) and the suburban site (bottom: DIAPASON) during both seasons. Mean concentrations (traces) and the corresponding 25 th and 75 th percentiles (shaded areas) are shown.

tion also suggest similar boundary layer dynamics, the observed shift possibly results from traffic starting in the suburbs earlier in the morning and continuing slowly towards the city centre. In contrast to our observations, no distinct shift of the morning rush hour peak was observed between the two suburban and the urban measurement locations from BC measurements during the MEGAPOLI summer campaign in Paris (Freutel et al., 2013).

Mean HOA mass concentrations for the individual measurement campaigns range between 0.59 and $0.93 \mu \mathrm{g} \mathrm{m}^{-3}$. During the 2013 measurements (October/November) similar concentrations were obtained at the suburban site $\left(0.76 \pm 1.04 \mu \mathrm{g} \mathrm{m}^{-3}\right)$ and central Rome $\left(0.71 \pm 0.72 \mu \mathrm{g} \mathrm{m}^{-3}\right)$, whereas in 2014 higher concentrations were reached in central Rome $\left(0.93 \pm 0.73 \mu \mathrm{g} \mathrm{m}^{-3}\right)$ compared to the suburb $\left(0.59 \pm 0.60 \mu \mathrm{g} \mathrm{m}^{-3}\right)$. Overall, the contribution of traffic-related emissions (e.g. $\mathrm{HOA}, \mathrm{NO}_{x}$, $\mathrm{PAH})$ to local air pollutant levels was higher in central Rome, as already discussed in Sect. 4.1.

A factor associated with cooking emissions, COA (cooking OA), was obtained by PMF analysis of the OA measured at both locations and during both seasons. The COA mass spectra show prominent peaks at $m / z 41$ and 55 (Allan et al., 2010; Lanz et al., 2007) and a smaller contribution of $m / z 60$ and 73 (Mohr et al., 2009). Our COA mass spectra correlated well with those found by Faber et al. (2013) and Mohr et al. (2012) with $R^{2}=0.63-0.93$.

The COA diurnal cycles observed in central Rome (Fig. 11, upper panel) are consistent with results from previous studies (e.g. Allan et al., 2010; Mohr et al., 2012), showing highest concentrations in the late evening (around 22:00) and a smaller peak around midday (14:00-15:00). This pattern is generated by a combination of source strengths and boundary layer dynamics, with a typically increased boundary layer height during lunchtime compared to dinnertime.

In contrast, diurnal cycles of the COA factors measured at the suburban location in 2013 and 2014 (Fig. 11, lower panel) 
both show a peak in the evening, but only during DIAPASON2014 a slight and barely significant COA concentration increase was observed during lunchtime. This could be due to an insufficient separation of the COA and HOA factors during PMF analysis, which is also demonstrated in the COA morning peak of the DIAPASON2014 measurements. However, the missing midday peak also reflects the generally low abundance of cooking-related OA at the suburban measurement location. While there are strong cooking activities and a large abundance and closeness of restaurants around the central Rome site, potential sources in the immediate vicinity of the suburban site are scarce. At a distance of around $250 \mathrm{~m}$ from our monitoring site, a cafeteria served hot meals for lunch, but apparently our measurements were not strongly affected by its emissions.

Consistently, absolute mass concentrations of cookingrelated emissions were higher at the central Rome site $\left(0.70 \pm 1.00,0.65 \pm 0.69 \mu \mathrm{g} \mathrm{m}^{-3}\right.$ in 2013 and 2014 , respectively) compared to the suburban measurement location $\left(0.45 \pm 0.50,0.53 \pm 1.29 \mu \mathrm{g} \mathrm{m}^{-3}\right)$. Ranging between 8 and $29 \%$ of the total OA concentrations, cooking activities contribute significantly to (sub-) urban air pollution. During mealtimes the contribution of COA to total organics can be very high. For example, during lunch-/dinnertimes in central Rome, COA contributions to total organics were $35 \% / 53 \%$ (POPE2013) and 9\% / $25 \%$ (POPE2014). Similar observations were made during the MEGAPOLI winter measurements in Paris, where COA contributed on average 11-17\% to total OA (up to $35 \%$ during lunchtimes; Crippa et al., 2013a).

\subsubsection{Cigarette smoking emissions}

For both POPE campaigns in central Rome PMF analysis of the organic aerosol fraction resulted in a factor which could be associated with cigarette smoke (CSOA; excluded from Fig. 2). This was not very surprising, since cigarette smoking took place in the direct vicinity of the measurement location. The mass spectra of CSOA from both years show good correlation with each other $\left(R^{2}=0.7\right.$; Fig. 12). Very characteristic for the CSOA spectra is a peak at $m / z 84$ from $\mathrm{C}_{5} \mathrm{H}_{10} \mathrm{~N}^{+}$and a peak at $m / z 42$ resulting from the ion $\mathrm{C}_{2} \mathrm{H}_{4} \mathrm{~N}^{+}$(Fig. 12). Both ions are typically observed in EI mass spectra of nicotine (NIST: http://webbook.nist.gov, origin: Japan AIST/NIMC Database- Spectrum MS-NW-5705). $\mathrm{C}_{5} \mathrm{H}_{10} \mathrm{~N}^{+}$(N-methylpyrrolidine), which shows the strongest signal in the EI mass spectrum of nicotine, is generated by cleavage of the nicotine molecule into two heterocycles (Jacob and Byrd, 1999). Since nicotine is one of the most abundant particulate compounds identified in cigarette smoke samples (Rogge et al., 1994), its fragments are suitable tracers for cigarette emissions. While cigarette smokerelated aerosol has been found in AMS measurements previously (Faber et al., 2013; Fröhlich et al., 2015) and the detection of nicotine from cigarette smoke was mentioned
(Jayne et al., 2000), to our knowledge, the identification of the nicotine fragment $N$-methylpyrrolidine from analysis of HR-ToF-AMS data is reported here for the first time. The time series of $\mathrm{C}_{5} \mathrm{H}_{10} \mathrm{~N}^{+}$was used during the evaluation of the PMF results as tracer for CSOA, yielding good correlations $\left(R^{2}>0.9\right)$ with the time series of CSOA. The correlation of the time series of $\mathrm{C}_{2} \mathrm{H}_{4} \mathrm{~N}^{+}$with CSOA is slightly poorer $\left(0.83<R^{2}<0.9\right)$. Additionally, since the difference of the contribution of the ion $\mathrm{C}_{2} \mathrm{H}_{4} \mathrm{~N}^{+}$to the mass spectra of CSOA compared to the mass spectra of other factors is less pronounced than for the ion $\mathrm{C}_{5} \mathrm{H}_{10} \mathrm{~N}^{+}$the latter seems to be more specific for cigarette emissions than $\mathrm{C}_{2} \mathrm{H}_{4} \mathrm{~N}^{+}$. This is why the use of $\mathrm{C}_{5} \mathrm{H}_{10} \mathrm{~N}^{+}$as a tracer ion for cigarette emissions was favoured over the ion $\mathrm{C}_{2} \mathrm{H}_{4} \mathrm{~N}^{+}$.

The CSOA mass spectra from both POPE campaigns show reasonable to very good agreement with CSOA mass spectra reported by Faber et al. (2013) $\left(0.65<R^{2}<0.96\right)$. Some differences are observed between the mass spectra obtained for POPE2013 and POPE2014 in the relative fraction of $\mathrm{CO}_{2}^{+}$ and its related ions, which also affects the observed elemental ratios (Fig. 12). This results in a potential error in CSOA concentrations of less than $10 \%$ and is probably due to a PMF artefact and/or insufficient correction for gas phase $\mathrm{CO}_{2}$. Comparison with mass spectra of cigarette smoke obtained in the laboratory (Faber et al., 2013) shows a contribution of $\mathrm{CO}_{2}^{+}$more similar to the POPE2013 measurements. Further laboratory work to obtain more robust source spectra is needed to better constrain the expected f44 in CSOA mass spectra. Due to the low intensity of the $\mathrm{N}$-containing ions and a conservative selection of ions which were fitted in the mass spectra reported by Faber et al. (2013), the nicotine fragment $\left(\mathrm{C}_{5} \mathrm{H}_{10} \mathrm{~N}^{+}\right)$was not observed in their measurements of cigarette smoke. However, after reanalysis of the mass spectra with integration of the $\mathrm{C}_{5} \mathrm{H}_{10} \mathrm{~N}^{+}$ion in the fitting procedure, a contribution of the nicotine tracer ion is clearly visible (P. Faber, personal communication, 2016).

Furthermore, the time series of mass concentration of the CSOA factor clearly support its attribution to cigarette smoking emissions. The diurnal cycle of the CSOA factor strongly correlates with typical working hours at the measurement location and with the diurnal cycle of the marker fragment $\mathrm{C}_{5} \mathrm{H}_{10} \mathrm{~N}^{+}$( $R^{2}=0.98$ for POPE2013 and POPE2014), exemplarily shown for POPE2014 in Fig. 13 (top). Averaged CSOA mass concentrations for each day of the week (Fig. 13; bottom) show distinct differences between working days and weekends, when the administration of the hospital where the measurements took place was closed, supporting the attribution of this PMF factor to locally emitted CSOA. Very similar observations were made during the POPE2013 measurements.

Particles from cigarette smoke contributed 9-24\% (0.62$0.76 \mu \mathrm{g} \mathrm{m}^{-3}$ ) to the total organic aerosol mass measured at the location in central Rome. No indications of cigarette emissions were found during the DIAPASON measurements. This result shows a potentially strong influence on air qual- 


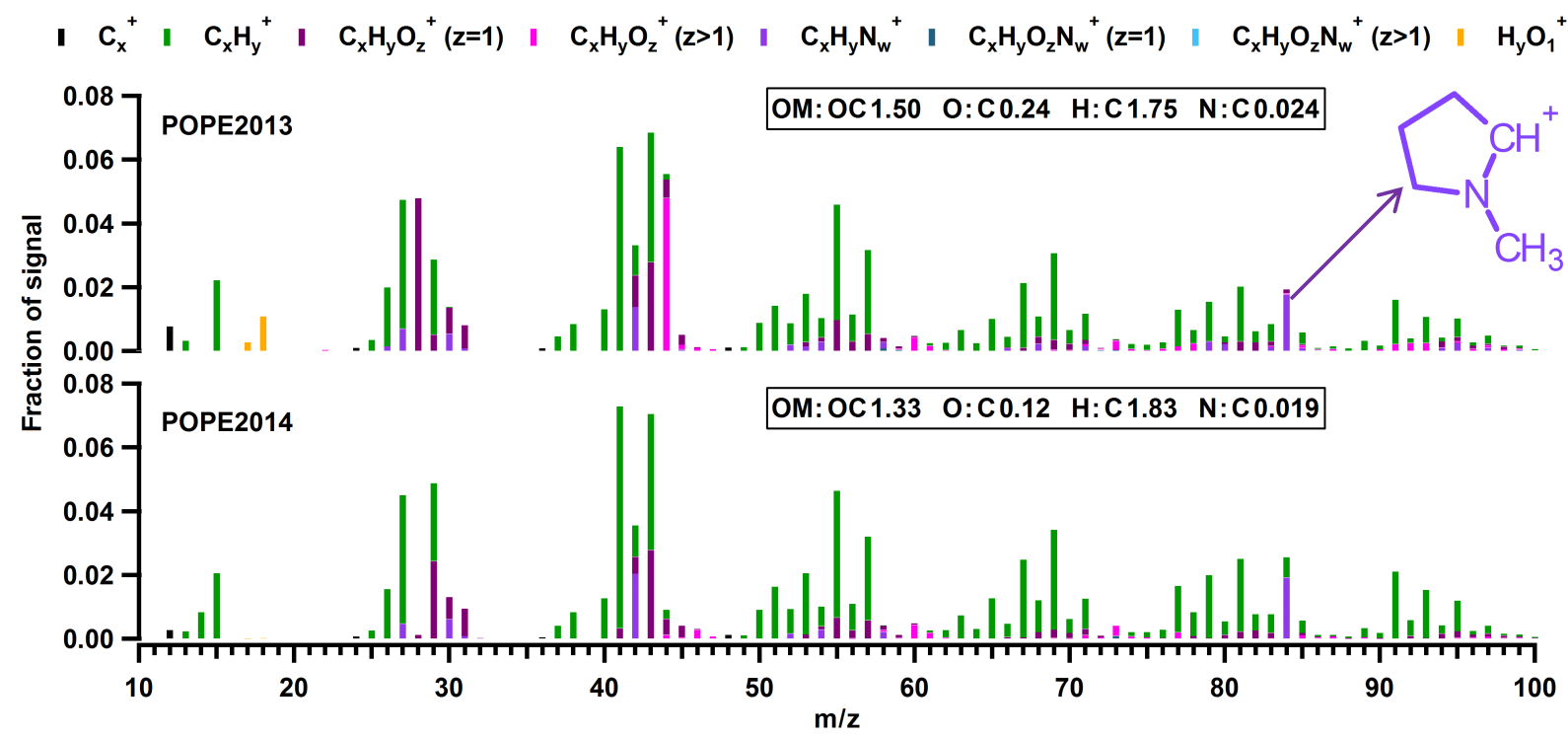

Figure 12. Unit mass resolution spectra of CSOA obtained for the two POPE campaigns, calculated from organic high-resolution mass spectra and colour coded for the different groups of ion fragments. The elemental ratios are shown in boxes. The chemical structure of the suggested ion fragment at $m / z 84\left(\mathrm{C}_{5} \mathrm{H}_{10} \mathrm{~N}^{+}\right)$is also illustrated.

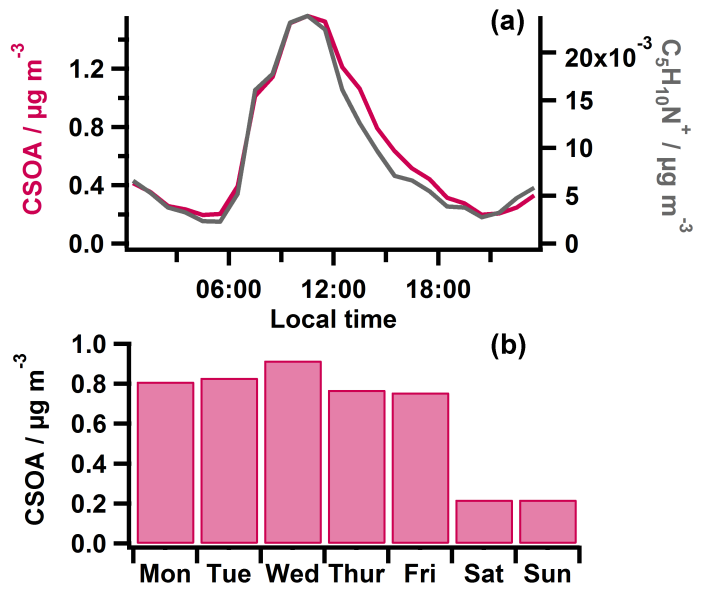

Figure 13. Diurnal cycle of CSOA and the marker fragment $\mathrm{C}_{5} \mathrm{H}_{10} \mathrm{~N}^{+}$(top) and the weekly cycle (bottom) of CSOA mass concentrations obtained from HR-AMS data of POPE2014.

ity in the direct environment of smokers, as also observed by Faber et al. (2013) and Fröhlich et al. (2015). Since in our measurement, CSOA is mostly produced close to the measurement location (i.e. it can be regarded a local contamination), it was not included in the previous analyses of organic aerosol composition (see Sect. 4.1).

$\mathrm{C}_{5} \mathrm{H}_{10} \mathrm{~N}^{+}$as a potential CSOA marker ion: The ion $\mathrm{C}_{5} \mathrm{H}_{10} \mathrm{~N}^{+}$was further investigated to assess its applicability and limitations as a tracer for cigarette emissions in AMS data sets. While the nicotine fragment ion $\mathrm{C}_{5} \mathrm{H}_{10} \mathrm{~N}^{+}$ $(m / z 84.08)$ seems to be unique to cigarette emissions, the proximity of the ions $\mathrm{C}_{5} \mathrm{H}_{8} \mathrm{O}^{+}(m / z 84.06)$ and $\mathrm{C}_{6} \mathrm{H}_{12}^{+}$ $(m / z$ 84.09) in the mass spectra causes interferences, since the mass resolution of the instrument ( $R \approx 2000$ in $V$-mode) is not sufficient for completely separating the individual ion signals. Mass spectra of the primary organic aerosol PMF factors (HOA, COA, BBOA) which are not related to cigarette emissions $\left(\mathrm{POA}_{\text {noCSOA }}\right)$ show significant contributions ( 0.2 to $0.7 \%$ of total organics mass spectral signal) of the ions $\mathrm{C}_{5} \mathrm{H}_{8} \mathrm{O}^{+}$and $\mathrm{C}_{6} \mathrm{H}_{12}^{+}$, leading to an artificial increase of the nicotine tracer ion signal. In contrast, for OOA mass spectra the contribution of these ions is comparatively low ( $0.1 \%$ of total organics mass spectral signal), which is why a potential interference of OOA was neglected in the following considerations.

AMS measurements performed during DIAPASON2013 and DIAPASON2014, which are assumed to be not influenced by local cigarette emissions, were used to quantify the concentration-dependent influence of $\mathrm{POA}_{\text {noCSOA }}$ on the nicotine tracer ion $\mathrm{C}_{5} \mathrm{H}_{10} \mathrm{~N}^{+}$due to fitting interferences from the neighbouring ions $\mathrm{C}_{5} \mathrm{H}_{8} \mathrm{O}^{+}$and $\mathrm{C}_{6} \mathrm{H}_{12}^{+}$. A linear relationship between $\mathrm{C}_{5} \mathrm{H}_{10} \mathrm{~N}^{+}$and $\mathrm{POA}_{\text {noCsOA }}$ was observed for a $\mathrm{POA}_{\text {noCSOA }}$ concentration range of $0-10 \mu \mathrm{g} \mathrm{m}^{-3}$. Using the mass contribution of $\mathrm{C}_{5} \mathrm{H}_{10} \mathrm{~N}^{+}$to the total CSOA mass spectra (Fig. 12; 1.8 and 1.9\% for POPE2013/2014, respectively), the corresponding ion signals were converted into CSOA detection limits. It was found that, under conservative considerations, CSOA concentrations of at least $10 \%$ of $\mathrm{POA}_{\text {noCSOA }}$ are needed to exceed detection limits. During conditions of negligible $\mathrm{POA}_{\text {noCSOA }}$ concentrations, a CSOA detection limit of $80 \mathrm{ng} \mathrm{m}^{-3}$ was estimated.

The same considerations were made for the ion $\mathrm{C}_{2} \mathrm{H}_{4} \mathrm{~N}^{+}$ to evaluate its applicability as a nicotine tracer. In contrast 
to $\mathrm{C}_{5} \mathrm{H}_{10} \mathrm{~N}^{+}$, the ion $\mathrm{C}_{2} \mathrm{H}_{4} \mathrm{~N}^{+}$seems to be less affected by its neighbouring ions. Therefore, we assume that its occurrence in the mass spectra of different PMF factors not only results from interferences of signals, but that $\mathrm{C}_{2} \mathrm{H}_{4} \mathrm{~N}^{+}$is also included in non-CSOA factors. However, the contribution of $\mathrm{C}_{2} \mathrm{H}_{4} \mathrm{~N}^{+}$to the CSOA mass spectra is higher than its contribution to those of other aerosol species (1-2 instead of $0.1-0.6 \%$ ). Therefore, we would recommend using $\mathrm{C}_{2} \mathrm{H}_{4} \mathrm{~N}^{+}$ as a second nicotine tracer, but only in combination with $\mathrm{C}_{5} \mathrm{H}_{10} \mathrm{~N}^{+}$.

Based on these estimations, it can be concluded that $\mathrm{C}_{5} \mathrm{H}_{10} \mathrm{~N}^{+}$is a suitable nicotine tracer ion for HR-AMS measurements, which are influenced by local cigarette emissions (i.e. CSOA larger than $10 \%$ of $\mathrm{POA}_{\text {noCSOA }}$ ) and can be used to estimate CSOA concentrations or to identify a CSOA factor from PMF analysis. Urban background concentrations of cigarette-related particles in the range of $1 \%$ of $\mathrm{PM}_{1}$, as reported by Rogge et al. (1994), however, are below the estimated CSOA detection limits. This is still true when considering typical contributions of OOA to total organics $(\sim 50 \%)$ and of OA to $\mathrm{PM}_{1}$ (also $\sim 50 \%$ ), leading to a CSOA detection limit of around $2.5 \%$ of $\mathrm{PM}_{1}$. To identify cigarette smoke contributions in the order of $1 \%$ of $\mathrm{PM}_{1}$, higher mass spectral resolution is needed to separate the nicotine tracer ion from its neighbouring ions. Nevertheless, the fitting of $\mathrm{C}_{5} \mathrm{H}_{10} \mathrm{~N}^{+}$at $m / z 84$ and $\mathrm{C}_{2} \mathrm{H}_{4} \mathrm{~N}^{+}$at $m / z 42$ could be worthwhile for HR-AMS data sets which are potentially influenced by cigarette-related particles. In future work, it should be investigated how aging processes affect the appearance of the marker ion $\mathrm{C}_{5} \mathrm{H}_{10} \mathrm{~N}^{+}$in the mass spectra.

\section{Summary and conclusions}

Intensive field campaigns have been carried out in October/November 2013 and May/June 2014, each time consecutively at two locations (suburban, urban) in the area of Rome, enabling the study of seasonal and spatial differences of aerosol and trace gas characteristics.

During both years at the suburban location an impact of advected Saharan dust on $\mathrm{PM}_{10}$ levels was detected. With respect to background conditions, increases of $\mathrm{PM}_{10}$ by 150 (2013) and $100 \%$ (2014) were measured, corresponding to average absolute increases of about $12-17 \mu \mathrm{g} \mathrm{m}^{-3}$. No influence of the dust occurrence on the non-refractory $\mathrm{PM}_{1}$ chemical composition was found during the advections.

At both locations, during the October/November measurements air quality was more strongly influenced by primary emissions (e.g. $\mathrm{BC}, \mathrm{NO}_{x}, \mathrm{PAH}$ ) with generally increased particle number concentration (PNC), whereas in May/June the contribution from secondary particles (sulfate, aged OA) and ozone was more important. Also in May/June 2014, new particle formation was frequently detected around midday, while in the colder season no distinct increase of PNC took place outside typical rush hour times. The consequence of higher temperatures plus stronger solar radiation was also visible in the SOA-related fraction of the organic aerosol. In the warmer season two types of OOA (less oxidized, fresher SVOOA and strongly oxidized, older LV-OOA) were identified, while in the colder season only strongly oxidized OOA was found.

Typical tracers for anthropogenic emissions $\left(\mathrm{CO}_{2}, \mathrm{NO}_{x}\right.$, $\mathrm{PAH}, \mathrm{HOA}, \mathrm{COA}$ ) were increased at the urban measurement location. However, absolute concentrations of POA were higher at the suburban location, due to a strong contribution from biomass burning OA, which accounted for $1.28 \mu \mathrm{g} \mathrm{m}^{-3}$ ( $24 \%$ of total OA) and for $0.82 \mu \mathrm{g} \mathrm{m}^{-3}$ (18\% of total OA) in October/November 2013 and May/June 2014, respectively. To a large degree this was related to agricultural waste burning in the surrounding areas and in October/November 2013 it was potentially also related to residential wood burning in the urban periphery.

Cooking- and traffic-related aerosols were observed at both locations during both seasons. The diurnal cycles of HOA (traffic-related OA) always peaked during rush hour times. A time shift in the morning rush hour peak between the suburban site and central Rome was observed, probably as a consequence of traffic progressing from the suburbs to the city centre. HOA accounted for 0.59 to $0.93 \mu \mathrm{g} \mathrm{m}^{-3}$ (13 to $29 \%$ of OA) at the different locations and seasons. COA, as an indicator of cooking activities, showed maximum concentrations during lunch and dinnertimes in central Rome, whereas at the suburban location only during dinnertimes distinct peaks were observed. Average COA mass concentrations of 0.45 to $0.70 \mu \mathrm{g} \mathrm{m}^{-3}$ ( 8 to $29 \%$ of OA) were found, with higher concentrations observed in central Rome compared to the suburban location $(2013:+50 ; 2014:+23 \%)$, as expected due to the higher density of related sources.

A type of $\mathrm{OA}$ related to nearby cigarette emissions (CSOA) was detected in central Rome and found to strongly correlate with a characteristic nicotine fragment $(N-$ methylpyrrolidine, $\mathrm{C}_{5} \mathrm{H}_{10} \mathrm{~N}^{+}$) at $m / z 84$ in the mass spectra. This ion could serve as a suitable tracer for locally emitted cigarette smoke for other data sets. However, in order to identify CSOA based solely on this tracer ion, CSOA must account for at least $10 \%$ of the sum of COA, HOA and $\mathrm{BBOA}$, due to interferences of neighbouring ion signals from these POA types. In the absence of those, a detection limit of $80 \mathrm{ng} \mathrm{m}^{-3}$ was found for CSOA. These findings imply that the resolution of the HR-AMS is not sufficient to identify urban background contributions of cigarette emissions $(\sim 1 \%$ of $\mathrm{PM}_{1}$, Rogge et al., 1994) based solely on $\mathrm{C}_{5} \mathrm{H}_{10} \mathrm{~N}^{+}$, while fitting of this ion could be worthwhile for HR-AMS data sets, which are potentially influenced by nearby cigarette emissions.

During our measurements submicron aerosol originating from sources in the metropolitan area of Rome and particles being advected from outside (dust periods were excluded) contributed $42-70$ and $30-58 \%$ to total measured $\mathrm{PM}_{1}$, re- 
spectively. Thus, during our measurements approximately half of the locally measured $\mathrm{PM}_{1}$ was home-made.

While for individual aerosol types clear spatial and temporal characteristics were observed and can be understood, no general conclusion can be drawn as to whether total aerosol mass concentrations are generally higher in the suburb or the city centre. Instead, consistently with observations made in the area of Paris (Freutel et al., 2013), it was found that aerosol levels strongly depend on the combination of meteorological conditions (e.g. origin of air masses, dilution capacity within the boundary layer) and contributions of secondary aerosols and local emissions.

\section{Data availability}

Data are available upon request to the contact author Frank Drewnick (frank.drewnick@mpic.de).

\section{The Supplement related to this article is available online at doi:10.5194/acp-16-15277-2016-supplement.}

Acknowledgements. The authors thank F. Barnaba, L. Di Liberto, F. Costabile and D. Dionisi of the DIAPASON team for their support and cooperation during and after the campaigns. We gratefully thank Thomas Böttger, Antonios Dragoneas and the hospital Santo Spirito in Sassia for logistical and technical support during the field campaigns. We also thank the Arpa Lazio Environmental Agency for providing TKE data, the Barcelona Supercomputing Center for providing the BSC-DREAM8b model outputs and NOAA Air Resources Laboratory (ARL) for the provision of the HYSPLIT transport and dispersion model. Franziska Köllner and Daniel Kunkel are gratefully acknowledged for providing the FLEXPART data. We thank anonymous reviewer \#2 for helpful comments regarding $m / z, 42$ as a potential nicotine tracer.

The article processing charges for this open-access publication were covered by the Max Planck Society.

Edited by: J. Allan

Reviewed by: three anonymous referees

\section{References}

Aiken, A. C., DeCarlo, P. F., and Jimenez, J. L.: Elemental analysis of organic species with electron ionization high-resolution mass spectrometry, Anal. Chem., 79, 8350-8358, 2007.

Alam, A., Shi, J. P., and Harrison, R. M.: Observations of new particle formation in urban air, J. Geophys. Res.-Atmos., 108, 4093, 2003.

Alfarra, M. R., Coe, H., Allan, J. D., Bower, K. N., Boudries, H., Canagaratna, M. R., Jimenez, J. L., Jayne, J. T., Garforth, A. A.,
Li, S. M., and Worsnop, D. R.: Characterization of urban and rural organic particulate in the lower Fraser valley using two aerodyne aerosol mass spectrometers, Atmos. Environ., 38, 57455758, 2004.

Allan, J. D., Williams, P. I., Morgan, W. T., Martin, C. L., Flynn, M. J., Lee, J., Nemitz, E., Phillips, G. J., Gallagher, M. W., and Coe, H.: Contributions from transport, solid fuel burning and cooking to primary organic aerosols in two UK cities, Atmos. Chem. Phys., 10, 647-668, doi:10.5194/acp-10-647-2010, 2010.

Alpert, P., Krichak, S. O., Tsidulko, M., Shafir, H., and Joseph, J. H.: A dust prediction system with TOMS initialization, Mon. Weather Rev., 130, 2335-2345, 2002.

Angelini, F. and Gobbi, G. P.: Some remarks about lidar data preprocessing and different implementations of the gradient method for determining the aerosol layers, Ann. Geophys., 57, A0218, 2014.

Barnaba, F. and Gobbi, G. P.: Aerosol seasonal variability over the Mediterranean region and relative impact of maritime, continental and Saharan dust particles over the basin from MODIS data in the year 2001, Atmos. Chem. Phys., 4, 2367-2391, doi:10.5194/acp-4-2367-2004, 2004.

Barnaba, F., Bolignano, A., Di Liberto, L., Morelli, M., Lucarelli, F., Nava, S., Perrino, C., Canepari, S., Basart, S., Costabile, F., Dionisi, D., Ciampichetti, S., Sozzi, R., and Gobbi, G. P.: Desert dust contribution to PM10 levels in Italy: results from an automated method building on and upgrading the relevant European Commission Guidelines in support to the Air Quality Directive 2008/50, Atmos. Environ., submitted, 2016.

Basart, S., Perez, C., Nickovic, S., Cuevas, E., and Maria Baldasano, J.: Development and evaluation of the BSC-DREAM8b dust regional model over Northern Africa, the Mediterranean and the Middle East, Tellus B, 64, 18539, 2012.

Boucher, O., Randall, D., Artaxo, P., Bretherton, C., Feingold, G., Forster, P., Kerminen, V.-M., Kondo, Y., Liao, H., Lohmann, U., Rasch, P., Satheesh, S. K., Sherwood, S., Stevens, B., and Zhang, X. Y.: Clouds and Aerosols, in: Climate Change 2013: The Physical Science Basis, Contribution of Working Group I to the Fifth Assessment Report of the Intergovernmental Panel on Climate Change, Cambridge, United Kingdom and New York, NY, USA, 2013.

Bougiatioti, A., Stavroulas, I., Kostenidou, E., Zarmpas, P., Theodosi, C., Kouvarakis, G., Canonaco, F., Prévôt, A. S. H., Nenes, A., Pandis, S. N., and Mihalopoulos, N.: Processing of biomassburning aerosol in the eastern Mediterranean during summertime, Atmos. Chem. Phys., 14, 4793-4807, doi:10.5194/acp-144793-2014, 2014.

Brines, M., Dall'Osto, M., Beddows, D. C. S., Harrison, R. M., Gómez-Moreno, F., Núñez, L., Artíñano, B., Costabile, F., Gobbi, G. P., Salimi, F., Morawska, L., Sioutas, C., and Querol, X.: Traffic and nucleation events as main sources of ultrafine particles in high-insolation developed world cities, Atmos. Chem. Phys., 15, 5929-5945, doi:10.5194/acp-15-5929-2015, 2015.

Canagaratna, M. R., Jayne, J. T., Jimenez, J. L., Allan, J. D., Alfarra, M. R., Zhang, Q., Onasch, T. B., Drewnick, F., Coe, H., Middlebrook, A., Delia, A., Williams, L. R., Trimborn, A. M., Northway, M. J., DeCarlo, P. F., Kolb, C. E., Davidovits, P., and Worsnop, D. R.: Chemical and microphysical characterization of ambient aerosols with the aerodyne aerosol mass spectrometer, Mass Spectrom. Rev., 26, 185-222, 2007. 
Canagaratna, M. R., Jimenez, J. L., Kroll, J. H., Chen, Q., Kessler, S. H., Massoli, P., Hildebrandt Ruiz, L., Fortner, E., Williams, L. R., Wilson, K. R., Surratt, J. D., Donahue, N. M., Jayne, J. T., and Worsnop, D. R.: Elemental ratio measurements of organic compounds using aerosol mass spectrometry: characterization, improved calibration, and implications, Atmos. Chem. Phys., 15, 253-272, doi:10.5194/acp-15-253-2015, 2015.

Carslaw, D. C., Beevers, S. D., Ropkins, K., and Bell, M. C.: Detecting and quantifying aircraft and other on-airport contributions to ambient nitrogen oxides in the vicinity of a large international airport, Atmos. Environ., 40, 5424-5434, 2006.

Costabile, F., Amoroso, A., and Wang, F.: Sub- $\mu$ m particle size distributions in a suburban Mediterranean area. Aerosol populations and their possible relationship with HONO mixing ratios, Atmos. Environ., 44, 5258-5268, 2010.

Crippa, M., DeCarlo, P. F., Slowik, J. G., Mohr, C., Heringa, M. F., Chirico, R., Poulain, L., Freutel, F., Sciare, J., Cozic, J., Di Marco, C. F., Elsasser, M., Nicolas, J. B., Marchand, N., Abidi, E., Wiedensohler, A., Drewnick, F., Schneider, J., Borrmann, S., Nemitz, E., Zimmermann, R., Jaffrezo, J.-L., Prévôt, A. S. H., and Baltensperger, U.: Wintertime aerosol chemical composition and source apportionment of the organic fraction in the metropolitan area of Paris, Atmos. Chem. Phys., 13, 961-981, doi:10.5194/acp-13-961-2013, 2013a.

Crippa, M., El Haddad, I., Slowik, J. G., DeCarlo, P. F., Mohr, C., Heringa, M. F., Chirico, R., Marchand, N., Sciare, J., Baltensperger, U., and Prevot, A. S. H.: Identification of marine and continental aerosol sources in Paris using high resolution aerosol mass spectrometry, J. Geophys. Res.-Atmos., 118, 1950-1963, $2013 b$.

DeCarlo, P. F., Kimmel, J. R., Trimborn, A., Northway, M. J., Jayne, J. T., Aiken, A. C., Gonin, M., Fuhrer, K., Horvath, T., Docherty, K. S., Worsnop, D. R., and Jimenez, J. L.: Field-Deployable, High-Resolution, Time-of-Flight Aerosol Mass Spectrometer, Anal. Chem., 78, 8281-8289, 2006.

DeCarlo, P. F., Ulbrich, I. M., Crounse, J., de Foy, B., Dunlea, E. J., Aiken, A. C., Knapp, D., Weinheimer, A. J., Campos, T., Wennberg, P. O., and Jimenez, J. L.: Investigation of the sources and processing of organic aerosol over the Central Mexican Plateau from aircraft measurements during MILAGRO, Atmos. Chem. Phys., 10, 5257-5280, doi:10.5194/acp-10-52572010, 2010.

DIAPASON: available at: http://www.diapason-life.eu/index. php?option=com_content $\&$ view $=$ article $\&$ id=171\&Itemid $=$ 466\&lang=en, last access: 18 November 2016.

Drewnick, F., Böttger, T., von der Weiden-Reinmüller, S.-L., Zorn, S. R., Klimach, T., Schneider, J., and Borrmann, S.: Design of a mobile aerosol research laboratory and data processing tools for effective stationary and mobile field measurements, Atmos. Meas. Tech., 5, 1443-1457, doi:10.5194/amt-5-1443-2012, 2012.

Faber, P., Drewnick, F., Veres, P. R., Williams, J., and Borrmann, S.: Anthropogenic sources of aerosol particles in a football stadium: Real-time characterization of emissions from cigarette smoking, cooking, hand flares, and color smoke bombs by high-resolution aerosol mass spectrometry, Atmos. Environ., 77, 1043-1051, 2013

Freutel, F., Schneider, J., Drewnick, F., von der Weiden-Reinmüller, S.-L., Crippa, M., Prévôt, A. S. H., Baltensperger, U., Poulain,
L., Wiedensohler, A., Sciare, J., Sarda-Estève, R., Burkhart, J. F., Eckhardt, S., Stohl, A., Gros, V., Colomb, A., Michoud, V., Doussin, J. F., Borbon, A., Haeffelin, M., Morille, Y., Beekmann, M., and Borrmann, S.: Aerosol particle measurements at three stationary sites in the megacity of Paris during summer 2009: meteorology and air mass origin dominate aerosol particle composition and size distribution, Atmos. Chem. Phys., 13, 933-959, doi:10.5194/acp-13-933-2013, 2013.

Fröhlich, R., Cubison, M. J., Slowik, J. G., Bukowiecki, N., Canonaco, F., Croteau, P. L., Gysel, M., Henne, S., Herrmann, E., Jayne, J. T., Steinbacher, M., Worsnop, D. R., Baltensperger, U., and Prévôt, A. S. H.: Fourteen months of on-line measurements of the non-refractory submicron aerosol at the Jungfraujoch (3580 m a.s.1.) - chemical composition, origins and organic aerosol sources, Atmos. Chem. Phys., 15, 11373-11398, doi:10.5194/acp-15-11373-2015, 2015.

Fuller, G. W., Sciare, J., Lutz, M., Moukhtar, S., and Wagener, S.: New Directions: Time to tackle urban wood burning?, Atmos. Environ., 68, 295-296, 2013.

Fuzzi, S., Baltensperger, U., Carslaw, K., Decesari, S., Denier van der Gon, H., Facchini, M. C., Fowler, D., Koren, I., Langford, B., Lohmann, U., Nemitz, E., Pandis, S., Riipinen, I., Rudich, Y., Schaap, M., Slowik, J. G., Spracklen, D. V., Vignati, E., Wild, M., Williams, M., and Gilardoni, S.: Particulate matter, air quality and climate: lessons learned and future needs, Atmos. Chem. Phys., 15, 8217-8299, doi:10.5194/acp-15-8217-2015, 2015.

Gariazzo, C., Argentini, S., Balducci, C., Bogliolo, M. P., Cecinato, A., Cesaroni, G., Cristofari, A., D’Allura, A., Finardi, S., Forastiere, F., Gatto, M. P., Gherardi, M., Gordiani, A., Hänninen, O., Lamberti, M., Pelliccioni, A., Perilli, M., Perrino, C., Porta, D., Radice, P., Romagnoli, P., Sacco, F., Silibello, C., Stafoggia, M., and Tofful, L.: Biomass burning contribution to PAHs concentration in the urban area of Rome, Main findings from the LIFE+ EXPAH project and further observations, 10th International Conference on Air Quality - Science and Application, Milan, Italy, 2016.

Gobbi, G. P., Barnaba, F., and Ammannato, L.: The vertical distribution of aerosols, Saharan dust and cirrus clouds in Rome (Italy) in the year 2001, Atmos. Chem. Phys., 4, 351-359, doi:10.5194/acp-4-351-2004, 2004.

Gobbi, G. P., Angelini, F., Barnaba, F., Costabile, F., Baldasano, J. M., Basart, S., Sozzi, R., and Bolignano, A.: Changes in particulate matter physical properties during Saharan advections over Rome (Italy): a four-year study, 2001-2004, Atmos. Chem. Phys., 13, 7395-7404, doi:10.5194/acp-13-7395-2013, 2013.

Harrison, R. M., Grenfell, J. L., Savage, N., Allen, A., Clemitshaw, K. C., Penkett, S., Hewitt, C. N., and Davison, B.: Observations of new particle production in the atmosphere of a moderately polluted site in eastern England, J. Geophys. Res.-Atmos., 105, 17819-17832, 2000.

Heal, M. R., Kumar, P., and Harrison, R. M.: Particles, air quality, policy and health, Chem. Soc. Rev., 41, 6606-6630, 2012.

Hildemann, L. M., Markowski, G. R., and Cass, G. R.: Chemical composition of emissions from urban sources of fine organic aerosol, Environ. Sci. Technol., 25, 744-759, 1991.

Jacob III, P. and Byrd, G. D.: Chapter 6 - Use of gas chromatographic and mass spectrometric techniques for the determination of nicotine and its metabolites, in: Analytical Determination of 
Nicotine and Related Compounds and their Metabolites, Elsevier Science, Amsterdam, 1999.

Jayne, J. T., Leard, D. C., Zhang, X., Davidovits, P., Smith, K. A., Kolb, C. E., and Worsnop, D. R.: Development of an Aerosol Mass Spectrometer for Size and Composition Analysis of Submicron Particles, Aerosol Sci. Technol., 33, 49-70, 2000.

Jimenez, J. L., Canagaratna, M. R., Donahue, N. M., Prevot, A. S. H., Zhang, Q., Kroll, J. H., DeCarlo, P. F., Allan, J. D., Coe, H., Ng, N. L., Aiken, A. C., Docherty, K. S., Ulbrich, I. M., Grieshop, A. P., Robinson, A. L., Duplissy, J., Smith, J. D., Wilson, K. R., Lanz, V. A., Hueglin, C., Sun, Y. L., Tian, J., Laaksonen, A., Raatikainen, T., Rautiainen, J., Vaattovaara, P., Ehn, M., Kulmala, M., Tomlinson, J. M., Collins, D. R., Cubison, M. J., Dunlea, E. J., Huffman, J. A., Onasch, T. B., Alfarra, M. R., Williams, P. I., Bower, K., Kondo, Y., Schneider, J., Drewnick, F., Borrmann, S., Weimer, S., Demerjian, K., Salcedo, D., Cottrell, L., Griffin, R., Takami, A., Miyoshi, T., Hatakeyama, S., Shimono, A., Sun, J. Y., Zhang, Y. M., Dzepina, K., Kimmel, J. R., Sueper, D., Jayne, J. T., Herndon, S. C., Trimborn, A. M., Williams, L. R., Wood, E. C., Middlebrook, A. M., Kolb, C. E., Baltensperger, U., and Worsnop, D. R.: Evolution of Organic Aerosols in the Atmosphere, Science, 326, 1525-1529, 2009.

Kallos, G., Nickovic, S., Papadopoulos, A., Jovic, D., Kakaliagou, O., Misirlis, N., Boukas, L., Mimikou, N., Sakellaridis, G., Papageorgiou, J., Anadranistakis, E., and Manousakis, M.: The regional weather forecasting system SKIRON: An overview, paper presented at the International Symposium on Regional Weather Prediction on Parallel Computer Environments, University of Athens, Athens, Greece, 15-17 Oct., 1997.

Kulmala, M. and Kerminen, V.-M.: On the formation and growth of atmospheric nanoparticles, Atmos. Res., 90, 132-150, 2008.

Lanz, V. A., Alfarra, M. R., Baltensperger, U., Buchmann, B., Hueglin, C., and Prévôt, A. S. H.: Source apportionment of submicron organic aerosols at an urban site by factor analytical modelling of aerosol mass spectra, Atmos. Chem. Phys., 7, 15031522, doi:10.5194/acp-7-1503-2007, 2007.

Lanz, V. A., Prévôt, A. S. H., Alfarra, M. R., Weimer, S., Mohr, C., DeCarlo, P. F., Gianini, M. F. D., Hueglin, C., Schneider, J., Favez, O., D'Anna, B., George, C., and Baltensperger, U.: Characterization of aerosol chemical composition with aerosol mass spectrometry in Central Europe: an overview, Atmos. Chem. Phys., 10, 10453-10471, doi:10.5194/acp-10-10453-2010, 2010.

Lucarelli, F., Calzolai, G., Chiari, M., Giannoni, M., Mochi, D., Nava, S., and Carraresi, L.: The upgraded external-beam PIXE/PIGE set-up at LABEC for very fast measurements on aerosol samples, Nucl. Instrum. Meth. B, 318, 55-59, 2014.

Minguillon, M. C., Brines, M., Perez, N., Reche, C., Pandolfi, M., Fonseca, A. S., Amato, F., Alastuey, A., Lyasota, A., Codina, B., Lee, H. K., Eun, H. R., Ahn, K. H., and Querol, X.: New particle formation at ground level and in the vertical column over the Barcelona area, Atmos. Res., 164, 118-130, 2015.

Mohr, C., Huffman, J. A., Cubison, M. J., Aiken, A. C., Docherty, K. S., Kimmel, J. R., Ulbrich, I. M., Hannigan, M., and Jimenez, J. L.: Characterization of Primary Organic Aerosol Emissions from Meat Cooking, Trash Burning, and Motor Vehicles with High-Resolution Aerosol Mass Spectrometry and Comparison with Ambient and Chamber Observations, Environ. Sci. Technol., 43, 2443-2449, 2009.
Mohr, C., DeCarlo, P. F., Heringa, M. F., Chirico, R., Slowik, J. G., Richter, R., Reche, C., Alastuey, A., Querol, X., Seco, R., Peñuelas, J., Jiménez, J. L., Crippa, M., Zimmermann, R., Baltensperger, U., and Prévôt, A. S. H.: Identification and quantification of organic aerosol from cooking and other sources in Barcelona using aerosol mass spectrometer data, Atmos. Chem. Phys., 12, 1649-1665, doi:10.5194/acp-12-1649-2012, 2012.

Nava, S., Becagli, S., Calzolai, G., Chiari, M., Lucarelli, F., Prati, P., Traversi, R., Udisti, R., Valli, G., and Vecchi, R.: Saharan dust impact in central Italy: An overview on three years elemental data records, Atmos. Environ., 60, 444-452, 2012.

Ng, N. L., Canagaratna, M. R., Zhang, Q., Jimenez, J. L., Tian, J., Ulbrich, I. M., Kroll, J. H., Docherty, K. S., Chhabra, P. S., Bahreini, R., Murphy, S. M., Seinfeld, J. H., Hildebrandt, L., Donahue, N. M., DeCarlo, P. F., Lanz, V. A., Prévôt, A. S. H., Dinar, E., Rudich, Y., and Worsnop, D. R.: Organic aerosol components observed in Northern Hemispheric datasets from Aerosol Mass Spectrometry, Atmos. Chem. Phys., 10, 46254641, doi:10.5194/acp-10-4625-2010, 2010.

Paatero, P. and Tapper, U.: Positive matrix factorization: A nonnegative factor model with optimal utilization of error estimates of data values, Environmetrics, 5, 111-126, 1994.

Perez, C., Nickovic, S., Baldasano, J. M., Sicard, M., Rocadenbosch, F., and Cachorro, V. E.: A long Saharan dust event over the western Mediterranean: Lidar, Sun photometer observations, and regional dust modeling, J. Geophys. Res.-Atmos., 111, D15214, 2006a.

Perez, C., Nickovic, S., Pejanovic, G., Baldasano, J. M., and Oezsoy, E.: Interactive dust-radiation modeling: A step to improve weather forecasts, J. Geophys. Res.-Atmos., 111, D16206, 2006b.

Pikridas, M., Sciare, J., Freutel, F., Crumeyrolle, S., von der Weiden-Reinmüller, S.-L., Borbon, A., Schwarzenboeck, A., Merkel, M., Crippa, M., Kostenidou, E., Psichoudaki, M., Hildebrandt, L., Engelhart, G. J., Petäjä, T., Prévôt, A. S. H., Drewnick, F., Baltensperger, U., Wiedensohler, A., Kulmala, M., Beekmann, M., and Pandis, S. N.: In situ formation and spatial variability of particle number concentration in a European megacity, Atmos. Chem. Phys., 15, 10219-10237, doi:10.5194/acp-15-10219-2015, 2015.

Reche, C., Querol, X., Alastuey, A., Viana, M., Pey, J., Moreno, T., Rodríguez, S., González, Y., Fernández-Camacho, R., de la Rosa, J., Dall'Osto, M., Prévôt, A. S. H., Hueglin, C., Harrison, R. M., and Quincey, P.: New considerations for PM, Black Carbon and particle number concentration for air quality monitoring across different European cities, Atmos. Chem. Phys., 11, 6207-6227, doi:10.5194/acp-11-6207-2011, 2011.

Reche, C., Viana, M., Amato, F., Alastuey, A., Moreno, T., Hillamo, R., Teinila, K., Saarnio, K., Seco, R., Penuelas, J., Mohr, C., Prevot, A. S. H., and Querol, X.: Biomass burning contributions to urban aerosols in a coastal Mediterranean City, Sci. Total Environ., 427, 175-190, 2012.

Rizza, U., Barnaba, F., Miglietta, M. M., Gobbi, G. P., Mangia, C., Di Liberto, L., Dionisi, D., Costabile, F., and Grasso, F.: WRFChem model simulations of a dust outbreak over the Central Mediterranean and comparison with multi-sensor desert dust observations, Atmos. Chem. Phys. Discuss., doi:10.5194/acp-2016627, in review, 2016. 
Rogge, W. F., Hildemann, L. M., Mazurek, M. A., and Cass, G. R.: Sources of Fine Organic Aerosol. 6. Cigarette Smoke in the Urban Atmosphere, Environ. Sci. Technol., 28, 1375-1388, 1994.

Schneider, J., Weimer, S., Drewnick, F., Borrmann, S., Helas, G., Gwaze, P., Schmid, O., Andreae, M. O., and Kirchner, U.: Mass spectrometric analysis and aerodynamic properties of various types of combustion-related aerosol particles, Int. J. Mass Spectrom., 258, 37-49, 2006.

Shi, J. P., Evans, D. E., Khan, A. A., and Harrison, R. M.: Sources and concentration of nanoparticles $(<10 \mathrm{~nm}$ diameter) in the urban atmosphere, Atmos. Environ., 35, 1193-1202, 2001.

Sibson, R.: A brief description of natural neighbour interpolation, in: Interpreting Multivariate Data, edited by: Barnett, I. V., Wiley, New York, USA, 1981.

Srivastava, M. K. and Sarthi, P. P.: Turbulent kinetic energy in the atmospheric surface layer during the summer monsoon, Meteorol. Appl., 9, 239-246, 2002.

Stafoggia, M., Zauli-Sajani, S., Pey, J., Samoli, E., Alessandrini, E., Basagana, X., Cernigliaro, A., Chiusolo, M., Demaria, M., Diaz, J., Faustini, A., Katsouyanni, K., Kelessis, A. G., Linares, C., Marchesi, S., Medina, S., Pandolfi, P., Perez, N., Querol, X., Randi, G., Ranzi, A., Tobias, A., Forastiere, F., and Grp, M.-P. S.: Desert Dust Outbreaks in Southern Europe: Contribution to Daily PM10 Concentrations and Short-Term Associations with Mortality and Hospital Admissions, Environ. Health Persp., 124, 413-419, 2016.

Stein, A. F., Draxler, R. R., Rolph, G. D., Stunder, B. J. B., Cohen, M. D., and Ngan, F.: NOAA's HYSPLIT Atmospheric Transport and Dispersion Modeling System, B. Am. Meteorol. Soc., 96, 2059-2077, 2015.

Stohl, A., Forster, C., Frank, A., Seibert, P., and Wotawa, G.: Technical note: The Lagrangian particle dispersion model FLEXPART version 6.2, Atmos. Chem. Phys., 5, 2461-2474, doi:10.5194/acp-5-2461-2005, 2005.
Ulbrich, I. M., Canagaratna, M. R., Zhang, Q., Worsnop, D. R., and Jimenez, J. L.: Interpretation of organic components from Positive Matrix Factorization of aerosol mass spectrometric data, Atmos. Chem. Phys., 9, 2891-2918, doi:10.5194/acp-9-2891-2009, 2009.

Weimer, S., Alfarra, M. R., Schreiber, D., Mohr, M., Prevot, A. S. H., and Baltensperger, U.: Organic aerosol mass spectral signatures from wood-burning emissions: Influence of burning conditions and wood type, J. Geophys. Res.-Atmos., 113, D10304, 2008.

Yu, K. N., Cheung, Y. P., Cheung, T., and Henry, R. C.: Identifying the impact of large urban airports on local air quality by nonparametric regression, Atmos. Environ., 38, 4501-4507, 2004.

Zhang, Q., Stanier, C. O., Canagaratna, M. R., Jayne, J. T., Worsnop, D. R., Pandis, S. N., and Jimenez, J. L.: Insights into the chemistry of new particle formation and growth events in Pittsburgh based on aerosol mass spectrometry, Environ. Sci. Technol., 38, 4797-4809, 2004.

Zhang, Q., Jimenez, J. L., Canagaratna, M. R., Ulbrich, I. M., Ng, N. L., Worsnop, D. R., and Sun, Y.: Understanding atmospheric organic aerosols via factor analysis of aerosol mass spectrometry: a review, Anal. Bioanal. Chem., 401, 3045-3067, 2011.

Zheng, M., Salmon, L. G., Schauer, J. J., Zeng, L. M., Kiang, C. S., Zhang, Y. H., and Cass, G. R.: Seasonal trends in PM2.5 source contributions in Beijing, China, Atmos. Environ., 39, 3967-3976, 2005. 